\title{
The provenance of the Devonian Old Red Sandstone of the Dingle Peninsula, SW Ireland; the earliest record of Laurentian and peri-Gondwanan sediment mixing in Ireland
}

\author{
Brenton J. Fairey ${ }^{1 *}$, Aidan Kerrison ${ }^{1}$, Patrick A. Meere ${ }^{1}$, Kieran F. Mulchrone ${ }^{2}$, \\ Mandy Hofmann ${ }^{3}$, Andreas Gärtner ${ }^{3}$, Benita-Lisette Sonntag ${ }^{3}$, Ulf Linnemann ${ }^{3}$, \\ Klaudia F. Kuiper ${ }^{4}$, Meg Ennis ${ }^{1}$, Chris Mark ${ }^{5}$, Nathan Cogné 5 \& David Chew ${ }^{5}$ \\ ${ }^{1}$ School of Biological, Earth and Environmental Sciences, University College Cork, Cork, Ireland \\ ${ }^{2}$ School of Applied Mathematics, University College Cork, Cork, Ireland \\ ${ }^{3}$ Senckenberg Naturhistorische Sammlungen Dresden, Museum für Mineralogie und Geologie, Königsbrücker Landstraße \\ 159, D-01109 Dresden, Germany \\ ${ }^{4}$ Faculty of Earth Sciences, Vrije Universiteit Amsterdam, De Boelelaan 1085, NL-1081 HV Amsterdam, The Netherlands \\ 5 Department of Geology, Museum Building, Trinity College Dublin, Dublin 2, Ireland \\ (D) B.J.F., 0000-0002-8506-2192; A.K., 0000-0001-7296-6945; K.F.M., 0000-0001-7673-3241; A.G., 0000-0002-1670-7305; \\ K.F.K., 0000-0001-6345-5019; C.M., 0000-0001-8978-4283; D.C., 0000-0002-6940-1035 \\ *Correspondence: brenton.fairey@gmail.com
}

\begin{abstract}
The Lower Old Red Sandstone in southern Ireland is hosted in the Early Devonian Dingle Basin, which lies immediately south of the Iapetus Suture on the Dingle Peninsula, County Kerry. The basin developed as a post-Caledonian pullapart structure prior to Acadian deformation, which in turn was followed by end-Carboniferous Variscan deformation. Detrital zircon $\mathrm{U}-\mathrm{Th}-\mathrm{Pb}$ geochronology is complemented by mica $\mathrm{Ar}-\mathrm{Ar}$ and apatite $\mathrm{U}-\mathrm{Pb}$ geochronology to gain a comprehensive understanding of the provenance of the Lower Devonian Lower Old Red Sandstone of the Dingle Basin and assess contributions of major tectonic components (e.g. Laurentia, Ganderia). Sedimentary rocks in the Lower Old Red Sandstone have similar detrital zircon age distributions, which are dominated by $c .1 .2 \mathrm{Ga}$ zircons as well as late Neoproterozoic grains. This indicates a dominant contribution of detritus of Laurentian affinity as well as contributions from westerly and southerly derived Ganderian detritus. Caledonian uplift of the area north of the Iapetus Suture would have facilitated a large contribution of (peri-)Laurentian material. The Upper Old Red Sandstone on the Dingle Peninsula has a distinctly different detrital zircon character including few late Neoproterozoic zircons and abundant zircons of $c .1 .05 \mathrm{Ga}$ age, indicating sediment derivation only from Laurentia and no recycling from the Lower Old Red Sandstone.
\end{abstract}

Supplementary material: The full detrital U-Pb zircon and apatite analytical dataset and the revised detrital mica age dataset are available at https://doi.org/10.6084/m9.figshare.c.3971862

Received 4 August 2017; revised 16 November 2017; accepted 22 November 2017

The Dingle Basin in County Kerry, SW Ireland represents the only record of Early Devonian sedimentation south of the Iapetus Suture in Ireland. Its structure records a critical period in the tectonic history and development of Ireland, having been affected by both the Acadian and Variscan orogenies (Meere \& Mulchrone 2006) Furthermore, the basin's sedimentary rocks offer an opportunity to understand the palaeogeography of the basin, possibly recording Grampian to Late Caledonian (430-420 Ma) detrital input following the final Silurian accretion of Ganderia to the margin of Laurentia.

Existing provenance studies (e.g. Todd 2000; Ennis et al. 2015) have greatly improved our understanding of the development and palaeogeography of the Dingle Basin. However, a comprehensive investigation utilizing detrital single-grain techniques has yet to be undertaken. Such a study would serve to elucidate regional sediment source contributions in a basin that is intimately associated with the Iapetus Suture (Todd 2000), arguably the most important structural entity in the Phanerozoic tectonic history of Ireland.

This study provides the first multiproxy (zircon, apatite, mica) single-grain datasets from the area, with the aim of determining the provenance of the Lower Old Red Sandstone in the Dingle Group of the Early Devonian Dingle Basin and assessing the roles of Laurentian and peri-Gondwanan domains in contributing detritus.
The study also considers the detrital zircon provenance of the Upper Old Red Sandstone on the Dingle Peninsula.

\section{Regional geology and review of terranes in the British Isles}

The oldest potential source of detrital zircons lies to the north of the Iapetus Suture Zone in the form of the long-lived Laurentian craton (Fig. 1). A compilation of existing detrital zircon data for known Laurentian sources (Fig. 2) shows three broad peaks that correspond to major crust-forming events that contributed to the formation of Laurentia (Cawood et al. 2007). These peaks occur in the Archean, Paleoproterozoic and Mesoproterozoic, recording essentially uninterrupted zircon production from 1.9 to $0.9 \mathrm{Ga}$. A major characteristic of detrital zircon distributions from this sector of the Laurentian continent is the absence of zircons of late Neoproterozoic age owing to the absence of an active margin on the Laurentian continent at this time (Pointon et al. 2012). The Rhinns Complex on the island of Inishtrahull off the north coast of County Donegal and the Annagh Gneiss Complex in County Mayo form the exposed Proterozoic Laurentian basement in Ireland, and are also the oldest rocks exposed in Ireland. The Grenville Orogeny, represented by the large peak in late Mesoproterozoic zircon ages in 


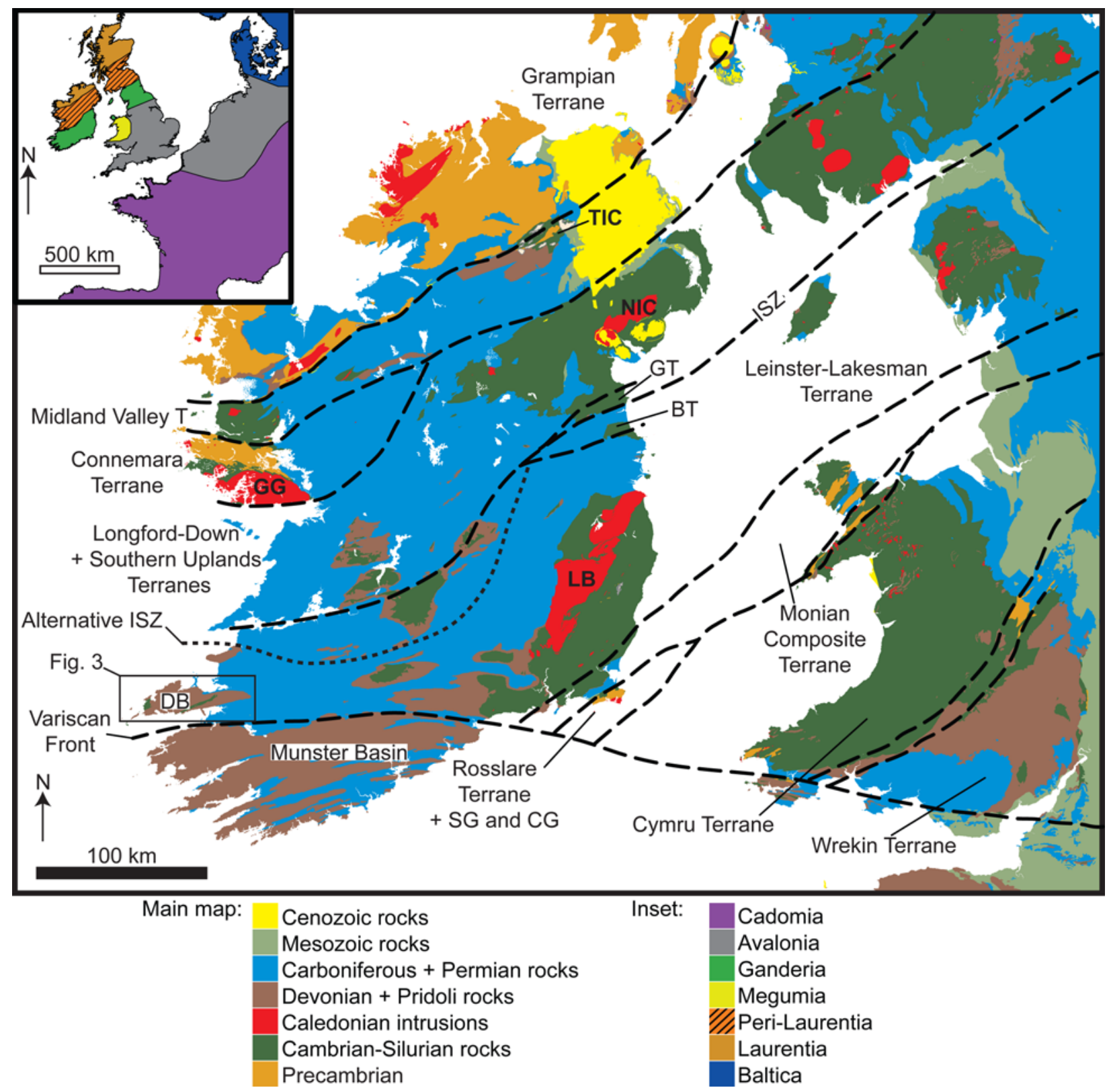

Fig. 1. Regional map of the British Isles showing the major terranes of Ireland. The rectangle indicates the study area shown in Figure 3 (modified after McIlroy \& Horák 2006; Waldron et al. 2014; McConnell et al. 2016; alternative Iapetus Suture Zone after Todd et al. 1991). Inset: regional map showing broad tectonic domains (Linnemann et al. 2007; Waldron et al. 2009, 2011, 2014; Nance et al. 2012). BT, Bellewstown Terrane; CG, Carnsore Granite; DB, Dingle Basin; GG, Galway Granite; GT, Grangegeeth Terrane; ISZ, Iapetus Suture Zone; LB, Leinster Batholith; NIC, Newry Igneous Complex; SG; Saltees Granite; TIC, Tyrone Igneous Complex.

Figure 2, is recorded in the Annagh Gneiss Complex by the $1.17 \mathrm{Ga}$ Doolough gneiss, the $1.01 \mathrm{Ga}$ Doolough Granite and by 0.99 0.96 Ga late orogenic pegmatites and migmatitic leucosomes (Daly 1996). A variety of marine sedimentary (e.g. Clew Bay Complex), ocean-arc-volcanic (e.g. Lough Nafooey Arc; see Chew et al. 2007) and ophiolitic rocks (e.g. Deer Park Complex) make up the material accreted to the margin of Laurentia during the Grampian Orogeny (465-475 Ma) in Ireland, which represents the early stage of the Caledonian orogenic cycle (Chew \& Stillman 2009). This was followed by sinistral transpressive docking of a peri-Gondwanan terrane to the newly accreted Laurentian margin (Dewey \& Strachan 2003).

The term 'peri-Gondwanide' was first proposed by Van der Voo (1988) to describe a number of tectonostratigraphic elements that existed as terranes in the Iapetus Ocean during the Ordovician period. Using palaeomagnetic evidence, Van der Voo (1988) suggested that these terranes were proximal to NW African Gondwana, rather than Laurentia. This has since been supported by other studies (see Nance et al. 2008, and references therein). We use the term 'domain' to refer to tectonostratigraphic units consisting of one or more terranes (Hibbard et al. 2007). PeriGondwanan domains include Avalonia, Ganderia, Megumia, Carolinia in present-day North America, and Avalonia and Cadomia (including Iberia, Bohemia and Armorica) in Europe (Nance et al. 2008). Those domains that had the potential, given their Devonian positions relative to southern Ireland, to provide sediment to the basin being investigated include Avalonia, Ganderia and Megumia. For a comprehensive review of periGondwanan terranes, the reader is referred to Nance et al. (2008). The correlation of the Meguma terrane to the Harlech Dome has been discussed by Waldron et al. (2011), White et al. (2012) and Nance et al. (2015). 


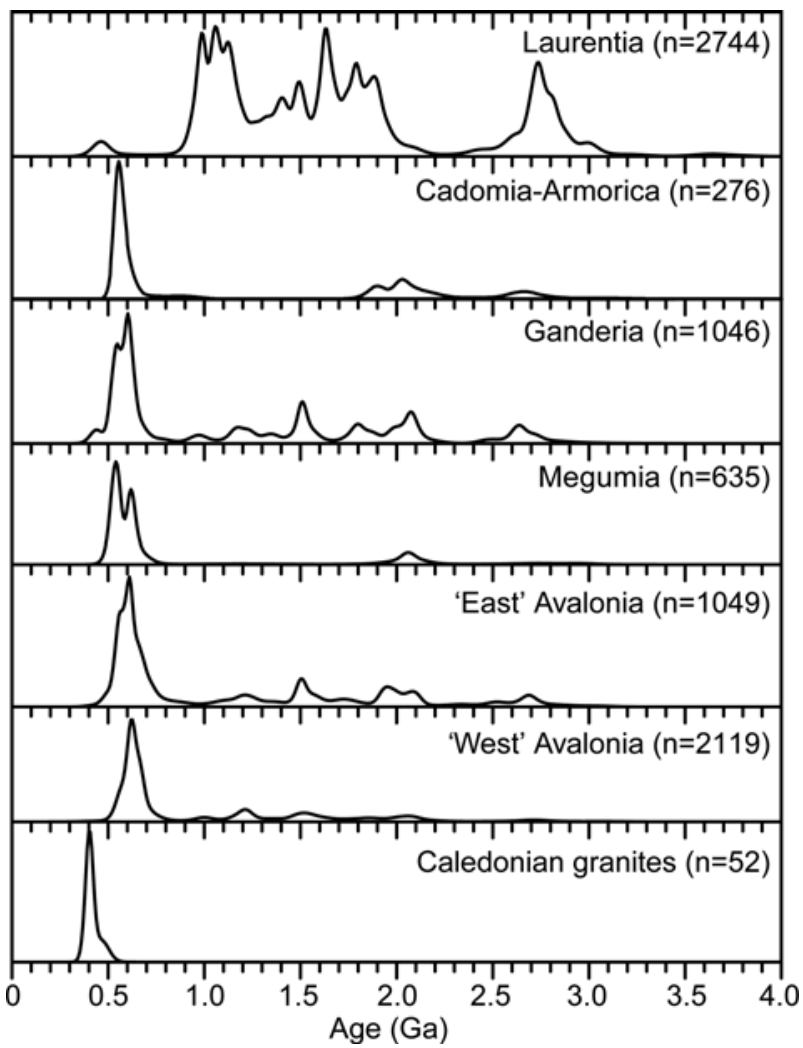

Fig. 2. Kernel density plots (bandwidth $20 \mathrm{Ma}$ ) of published detrital zircon ages from various potential source terranes (modified and expanded after Pointon et al. 2012). Laurentia data from Cawood et al. (2003, 2007, 2012), Friend et al. (2003), Kirkland et al. (2008), Waldron et al. (2008, 2014), McAteer et al. (2010), Strachan et al. (2013) and Johnson et al. (2016). Cadomia-Armorica data from Fernandez-Suarez et al. (2002), Samson et al. (2005), Linnemann et al. (2008) and Strachan et al. (2014). Ganderia data from Fyffe et al. (2009), Waldron et al. (2014) and Willner et al. (2014). Megumia data from Krogh \& Keppie (1990), Waldron et al. (2009, 2011) and Pothier et al. (2015). 'East' Avalonia data from Collins \& Buchan (2004), Murphy et al. (2004b), Strachan et al. (2007), Linnemann et al. (2012) and Willner et al. (2013). 'West' Avalonia data from Keppie et al. (1998), Thompson \& Bowring (2000), Barr et al. (2003, 2012), Murphy et al. (2004a, b), Pollock (2007), Satkoski et al. (2010), Dorais et al. (2012), Force \& Barr (2012), Pollock et al. (2012), Thompson et al. (2012), Willner et al. (2013) and Henderson et al.

(2016). Caledonian granite ages are from Ireland only and include various isotopic geochronological techniques. The Caledonian data are taken from Chew \& Stillman (2009).

The main rock exposures of pre-Devonian basement south of the Iapetus Suture Zone in Ireland are found in the Leinster Massif in the southeastern part of the island. The massif hosts a number of Cambrian to Silurian volcanic and sedimentary units intruded by Caledonian-Acadian granites. There has been wide acceptance that pre-Silurian southern Ireland represents part of Avalonia (e.g. Van der Voo 1983, 1988; Livermore et al. 1985; Pickering et al. 1988; Ford et al. 1992; Cocks et al. 1997; McConnell \& Morris 1997; Keppie et al. 2003; Tyrrell et al. 2007; Fullea et al. 2014; Todd 2015), but others have suggested linkages to different periGondwanan domains. One school of thought contends that southern Ireland, Wales and southern England formed part of a number of terranes that collectively formed Cadomia (e.g. Soper \& Hutton 1984; Max et al. 1990).

Kennedy (1979) first implied that southern Ireland is a transAtlantic extension of Ganderia. Van Staal et al. (1996) (and references therein) extended the Gander Zone of Newfoundland, where Ganderia was first described, into Ireland, Wales, England and the Isle of Man. As evidence of this they cited a correlation of
Cambrian and Ordovician clastic successions, a similarity of overstepping successions, juxtaposition of mafic to ultramafic, possibly ophiolitic rocks (e.g. Rosslare Complex) and a similarity in fossil fauna. This extension of Ganderia into southern Ireland was further supported by Van Staal et al. (1998), who suggested that Avalonia and Ganderia may have become juxtaposed at least during the late Cambrian. If this is the case, then it was an amalgamated Avalonia-Ganderia microcontinent that collided with Laurentia during the Caledonian Orogeny. More recently, Waldron et al. (2014) have drawn similarities between detrital zircon ages from Monian Composite Terrane (county Wexford) and LeinsterLakesman samples and samples analysed by Fyffe et al. (2009) for Ganderia in New Brunswick and Maine. The difference between Ganderian detrital zircon samples from Cambrian sedimentary rocks and West Avalonian samples is that the latter are lacking in Mesoproterozoic and Paleoproterozoic zircons (Waldron et al. 2014). Waldron et al. (2014) attributed these Mesoproterozoic and Paleoproterozoic zircons in Ganderian sediments to a possible Amazonian source in West Gondwana.

Distinguishing between Avalonia and Ganderia by detrital zircon populations alone is difficult (Fig. 2). Stratigraphic, faunal and other isotopic evidence is required, as exemplified in a review of the East Avalonian terranes by Schofield et al. (2016). They used geochronological data as well as magmatic whole-rock $\mathrm{Sm}-\mathrm{Nd}$ and O-isotopes to show that what is currently viewed as East Avalonian basement in England has closer isotopic and age affinities to Ganderia than to West Avalonia. Elimination of East Avalonia in the British Isles simplifies the interpretation of the provenance of Neoproterozoic detrital zircons in Devonian sedimentary rocks in the region. Although Ganderia is the most proximal potential source of Neoproterozoic zircons, one cannot eliminate the possible detrital influence from other peri-Gondwanan sources.

Waldron et al. (2011) proposed that the Cambrian successions of the Meguma terrane of Nova Scotia and the Harlech Dome of Wales be considered a single palaeogeographical domain, which they named 'Megumia'. They showed that detrital zircon age distributions from the Harlech Dome have greater similarity to those in the Meguma terrane than to those in Avalonia. The major difference in detrital zircon age distributions between Megumia and Avalonia is the significant presence of 1.95-2.1 Ga zircons in Megumia and the lack thereof in Avalonia. These zircon ages are believed to be associated with Eburnean orogenic magmatic activity (Waldron et al. 2011). For the purpose of this study, a significant contribution of Neoproterozoic zircon grains to the sediments under investigation is used predominantly as a tool to distinguish between periGondwana-derived and Laurentia-derived zircons, owing to the fact that Laurentia is not known to have any major source of Neoproterozoic zircons (Fig. 2). Furthermore, given the Devonian age and tectonic setting of the sediments, it is likely that they represent heterogeneous source areas. However, the reader is urged to bear in mind the complexities associated with sources of Neoproterozoic zircons in the British Isles, as described above.

The Grampian Orogeny, which occurred in the Ordovician period, is considered to be the first stage of the Caledonian orogenic cycle (Chew \& Stillman 2009) and records the collision of an oceanic arc (recognized in Ireland as the Lough Nafooey Arc) with the Laurentian margin (Chew \& Strachan 2014). Ordovician sediments from the South Mayo Trough record dominant input of zircons in the age range c. 490-c. $467 \mathrm{Ma}$ (McConnell et al. 2009). However, this range bears two populations, one around $487 \mathrm{Ma}$ and one between $c .474$ and c. $467 \mathrm{Ma}$, interpreted by McConnell et al. (2009) to be sourced from the Lough Nafooey Arc-Clew Bay Complex and the Connemara orthogneiss suite respectively. The Tyrone Igneous Complex is also of similar age to the Connemara suite (Cooper et al. 2011). The Grangegeeth volcanic terrane in 


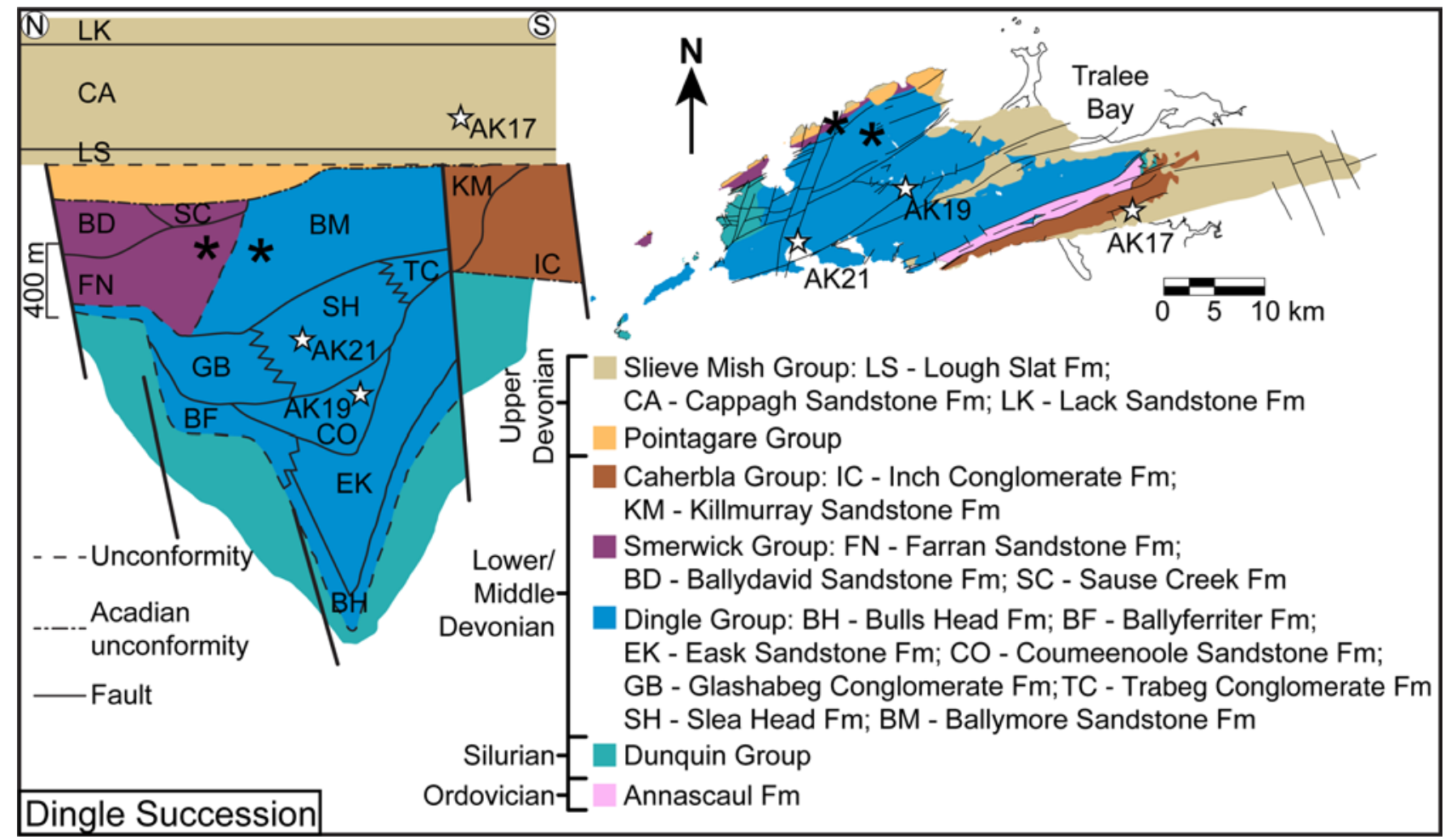

Fig. 3. Geological map and generalized north-south geological cross-section of the Dingle Peninsula showing sample locations (modified after Todd 1989; Ennis et al. 2015). Detrital apatite and detrital zircon sample location are marked by bold asterisks and white stars respectively.

eastern Ireland has a maximum age of c. $465 \mathrm{Ma}$ and inherited zircon within it indicate that it is of Laurentian origin, perhaps being related to the Tyrone Igneous Complex (McConnell et al. 2010). Its anomalous position south of the Southern Uplands-Longford Down terrane is attributed to transpressive strike-slip deformation in Middle Silurian times (McConnell et al. 2010). To the south of the Grangegeeth terrane lies the Bellewstown terrane (Fig. 1). This terrane is considered part of the Ganderian margin and zircons dated from a sandstone within a volcanogenic breccia place the age of volcanism in the terrane at c. $474 \mathrm{Ma}$ (McConnell et al. 2015).

Plagiogranite boulders from Silurian conglomerates that lie unconformably upon the Lough Nafooey Group are considered to be sourced from the Lough Nafooey Arc (Chew et al. 2007). U-Pb zircon ages of around $490 \mathrm{Ma}$ from these boulders, supported by Nd-isotope data, led Chew et al. (2007) to conclude that the arc had encountered Laurentian margin sediments by this time. This represents a source of Early Ordovician detrital zircons. The Southern Uplands-Longford Down terrane predominantly consists of Ordovician to Silurian metasedimentary rocks that were originally deposited in the Iapetus Ocean on the margin of Laurentia and were subsequently accreted to this margin (Waldron et al. 2008; McConnell et al. 2016). In Ireland, McConnell et al. (2016) found that these sediments contained Proterozoic zircons indicative of a Laurentian origin. In addition, their samples contained an abundance of Early to Middle Ordovician zircons, which they interpreted as representing a volcanic arc source (e.g. Tyrone Igneous Complex, Lough Nafooey Arc). In Scotland, Waldron et al. $(2008,2014)$ found that the majority of detrital zircons are of Proterozoic age and sourced from Laurentia. Generally, samples from these studies produced fewer Early to Middle Ordovician zircons relative to those from the Irish side of the terrane.

Another potentially important Ordovician zircon source occurs in the Duncannon and Ribband Groups in the Leinster Massif. The minor calc-alkaline volcanic rocks in the Ribband Group represent arc development during initial stages of subduction of the Iapetus
Ocean crust beneath Ganderia (East Avalonia) in Tremadocian times (Woodcock 2012). The Duncannon Group volcanic suite consists of basalts and rhyolites, extruded in Caradoc times (Sandbian-Katian), which are considered indicative of a back-arc region (Woodcock 2012). These volcanic suites have not yet been isotopically dated and their ages are largely constrained by faunal evidence in associated sedimentary successions (e.g. Owen \& Parkes 2000).

The final welding of Ganderia to the margin of Laurentia, which included an accreted ocean arc following the Grampian Orogeny, was achieved during the Caledonian Orogeny, by about 430-425 Ma (Mac Niocaill 2000; Waldron et al. 2014). However, abundant evidence of Late Caledonian (including Acadian, sensu Chew \& Stillman 2009) magmatism exists in the form of widely distributed intrusions in Ireland and Britain. These range in age from c. 430 to $380 \mathrm{Ma}$ (Fig. 2). An example of such an intrusion, which has been proposed as a proximal source of detritus to the Munster Basin (e.g. Penney 1980) and which represents the age of the majority of these intrusions (Fig. 2), is the Leinster granite batholith. O'Connor et al. (1989) obtained a U-Pb monazite age of $405 \pm 2 \mathrm{Ma}$ for the batholith. However, recent work by Fritschle et al. (2017) has shown that it was emplaced over an extended period from c. 417 to $405 \mathrm{Ma}$. Vermeulen et al. (2000) have shown, by seismic analysis of southern Ireland, that the Upper Old Red Sandstone south of the Killarney-Mallow Fault Zone is likely to be concealing a granitic body. Such an interpretation has been suggested by other studies (e.g. Ford et al. 1991; Meere 1995; Masson et al. 1998; Todd 2000; Vermeulen et al. 2000). Todd (2000) suggested that, based on clast analysis of the Trabeg Conglomerate Formation, a granite body similar to the Leinster Batholith was exposed in the southern hinterlands of the Dingle Basin during its development and that the Leinster terrane therefore extends westward following Caledonian trends. Other examples of intrusive rocks of Late Caledonian age in Ireland include the Donegal (418-388 Ma), Galway (412-380 Ma) and Newry Granites (403-387 Ma) and the Carnsore and Saltees Granites 
(436-428 Ma). The age ranges presented above are, in most cases, the result of dating by multiple geochronogical techniques, which yield different ages. The studies from which these ages are obtained have been reviewed by Chew \& Stillman (2009). The Newry Igneous Complex has recently been re-dated by Cooper et al. (2016), who showed that, like the Leinster Batholith, the complex was emplaced over a similarly extended period from 414 to $407 \mathrm{Ma}$.

Following the closure of the Iapetus Ocean, a Silurian to Early Devonian period of sinistral transtension accommodated deposition of the Lower Old Red Sandstone in the Dingle Basin and elsewhere in the southern British Isles (Todd 1989; Soper \& Woodcock 2003). This Emsian transtension across the Iapetus Suture Zone in Ireland and Britain possibly initiated emplacement of granites of similar age on either side of the Iapetus Suture Zone (Brown et al. 2008; Cooper et al. 2016). The rocks of the Dingle Basin record an Emsian deformational event, which is considered to be part of the Acadian orogenic episode (Todd 1989, 2000, 2015; Meere \& Mulchrone 2006). Deformation occurred in a transpressive regime but its kinematic character in the Dingle Basin is debated (e.g. Todd 1989, 2015; Meere \& Mulchrone 2006) because the structural fabrics within the Lower Old Red Sandstone are complicated by Carboniferous Variscan overprinting.

\section{Local geology and sample location}

The majority of the rocks that crop out on the Dingle Peninsula, SW Ireland, form part of the Lower to Middle Devonian Lower Old Red Sandstone of the Dingle Basin. Basement to this basin is also exposed on the peninsula in the form of the Ordovician Annascaul Formation and the Silurian Dunquin Group (Todd et al. 2000) (Fig. 3). These have been correlated with Ordovician and Silurian rocks in the Leinster Massif and therefore have a peri-Gondwanan affinity (Todd et al. 2000). The axis of the Dingle Basin approximates the regional NE-SW Caledonian trend in Ireland. The basin's sedimentary fill is complicated by a series of unconformities that separate five lithostratigraphic groups (Boyd \& Sloan 2000). Todd et al. (1988) considered the main mechanism of subsidence to be in the form of a sinistral pull-apart structure. Meere \& Mulchrone (2006) recognized two broad phases of extension: an Early Devonian phase that accommodated Dingle Basin sediments, and a Late Devonian to Carboniferous phase that accommodated the sediments of the Munster Basin. An intervening Middle Devonian transpression, probably recording the Acadian orogenic event (Dewey \& Strachan 2003; Soper \& Woodcock 2003), led Ennis et al. (2015) to consider the possibility of sedimentary recycling from the Dingle Basin into the Munster Basin. Such recycling of the Dingle Basin Lower Old Red Sandstone into the Upper Old Red Sandstone of the Munster Basin has also been suggested by Todd (2015).

Within the Dingle Basin, the Dingle Group, which is the most voluminous, represents a fluvial-alluvial environment in which axial (flowing from SW to NE along the basin axis) braid-plains and flood sheets, represented by the Eask, Coumeenoole, Slea Head and Ballymore formations, were deposited by generally perennial axial river systems that flowed from the SW (Todd 2000). These were abutted by alluvial fans, mainly represented by the Glashabeg Conglomerate Formation in the north and the Trabeg Conglomerate Formation in the south, that drained transversely into the basin (Todd 2000). Spores from the Eask and Slea Head Formation have yielded ages of Early Pragian and Early Emsian respectively (Higgs 1999). Two samples from the Lower Old Red Sandstone of the Dingle Basin were taken from the Coumeenoole Formation and the overlying Slea Head Formation from the Dingle Group (Fig. 3) in close proximity to the locations of equivalent samples from Ennis et al. (2015).
Todd (2000) carried out an extensive study of clasts from the correlative Glashabeg Conglomerate, Slea Head and Trabeg Conglomerate formations in the Early to Middle Devonian Dingle Basin. Based on the large number of mafic to intermediate volcanic clasts and the presence of limestone clasts in the Glashabeg Conglomerate Formation, he concluded that the source area was dominated by Ordovician volcanic rocks lying in close proximity to the north of the basin and probably intersecting the Iapetus Suture Zone. Rivers feeding the Slea Head Formation (and the conformably underlying Coumeenoole Formation, which has a similar palaeoflow direction) flowed axially through the basin toward the NE, draining an area to the SW (Todd 2000). Pebble clasts indicate sediment derivation from Silurian volcanic rocks and from an extension of the Leinster Massif basement (Todd 2000). The Trabeg Conglomerate Formation formed the southern flank of the Slea Head system and drained an area to the south and SW of the basin that was made up of rocks similar to those observed in the Leinster Massif (Todd 2000).

Unconformably overlying the Dingle Group is the Smerwick Group, which consists of sedimentary rocks of aeolian and fluvial origin (Todd et al. 1988). The two groups are truncated by an unconformity that developed as a result of erosion during Late Emsian Acadian basin inversion (Meere \& Mulchrone 2006). This was followed by deposition of the Pointagare Group, exposed only on the northern coast of the peninsula, and the Caherbla Group to the south, which contains the Inch Conglomerate Formation. These formations are thought to have been deposited in Middle Devonian (Eifelian) times (Todd 2015, and references therein). Finally, the overstepping sandstone and conglomerate successions of the Slieve Mish Group were deposited during the Late Devonian and were considered by Williams (2000) to be a correlative of the Ballinskelligs Formation and equivalents in the Munster Basin. Sample AK17 was obtained from a pebbly sandstone of the fluvial to lacustrine (Todd 2015) Cappagh Sandstone Formation of the Slieve Mish Group.

\section{Analytical procedures and sampling}

The apatite $\mathrm{U}-\mathrm{Pb}$ data were originally generated as part of a bedrock thermal history study utilizing the apatite fission-track (AFT) lowtemperature thermochronometer (Cogné et al. 2014), because the laser ablation inductively coupled plasma mass spectrometry (LAICP-MS) approach to AFT analysis permits U-Pb and AFT ages to be determined on the same grains during a single analytical session (Chew \& Donelick 2012). The sampling and separation process is therefore different from the zircon separation process.

\section{Zircon $\mathrm{U}-\mathrm{Pb}$}

Data to produce the source 'signals' shown in Figure 2 were derived from a number of sources. Data from samples interpreted to be of Laurentian origin were sourced from Cawood et al. (2003, 2007, 2012), Friend et al. (2003), Kirkland et al. (2008), Waldron et al. (2008, 2014), McAteer et al. (2010), Strachan et al. (2013) and Johnson et al. (2016). Data from samples interpreted to be derived from Cadomia-Armorica are from Fernandez-Suarez et al. (2002), Samson et al. (2005), Linnemann et al. (2008) and Strachan et al. (2014). Data from sample of Ganderian association are from Fyffe et al. (2009), Waldron et al. (2014) and Willner et al. (2014). Data from samples interpreted to be of Megumian affinity are from Krogh \& Keppie (1990), Waldron et al. $(2009,2011)$ and Pothier et al. (2015). 'East' Avalonia data were taken from Collins \& Buchan (2004), Murphy et al. (2004b), Strachan et al. (2007), Linnemann et al. (2012) and Willner et al. (2013). Data from samples interpreted to be sourced from 'West' Avalonia are from Keppie et al. (1998), Thompson \& Bowring (2000), Barr et al. (2003, 
2012), Murphy et al. (2004a,b), Pollock (2007), Satkoski et al. (2010), Dorais et al. (2012), Force \& Barr (2012), Pollock et al. (2012), Thompson et al. (2012), Willner et al. (2013) and Henderson et al. (2016). Caledonian granite ages are from Ireland only and were determined using various isotopic geochronological techniques. The granite data were sourced from a compilation by Chew \& Stillman (2009).

Sample separation was undertaken at Vrije Universiteit Amsterdam. Detrital zircons were liberated from samples using a jaw crusher and disc mill. Density separation was achieved using diiodomethane in a centrifuge, following the method of Ijlst (1973), and magnetic separation using a Frantz magnetic separator. Zircons of all morphologies and colours, between 60 and $250 \mu \mathrm{m}$, were hand-picked under binocular microscope. Typically, between 120 and 180 zircons per sample were mounted in epoxy discs and ground and polished to expose the approximate centre of the grains. Cathodoluminescence (CL) imaging was undertaken at the University of St Andrews and at Trinity College Dublin to identify optimal positions for laser ablation.

Uranium, thorium and lead isotopes were measured by laser ablation sector field inductively coupled plasma mass spectrometry (LA-SF-ICP-MS) at the Museum für Mineralogie und Geologie (Geoplasma Lab, Senckenberg Naturhistorische Sammlungen Dresden) using a Thermo-Scientific Element 2 XR sector field ICP-MS system coupled to a New Wave UP-193 excimer laser system. Each analysis consisted of $c$. $15 \mathrm{~s}$ background acquisition followed by $30 \mathrm{~s}$ data acquisition. A common- $\mathrm{Pb}$ correction based on the interference- and background-corrected ${ }^{204} \mathrm{~Pb}$ signal and a model $\mathrm{Pb}$ composition (Stacey \& Kramers 1975) was carried out if necessary. The necessity of the correction is judged on whether the corrected ${ }^{207} \mathrm{~Pb} /{ }^{206} \mathrm{~Pb}$ lies outside the internal errors of the measured ratios. Raw data were corrected for background signal, common $\mathrm{Pb}$, laser-induced elemental fractionation, instrumental mass discrimination, and time-dependant elemental fractionation of $\mathrm{Pb} / \mathrm{Th}$ and $\mathrm{Pb} / \mathrm{U}$ using a Microsoft Excel spreadsheet program developed by Axel Gerdes (Institute of Geosciences, Johann Wolfgang GoetheUniversity Frankfurt, Frankfurt am Main, Germany). Concordia diagrams and concordia ages were produced using Isoplot/Ex 3.7 of Ludwig (2012). Frequency and kernel density estimation (KDE) curves were plotted using DensityPlotter (Vermeesch 2012). Frequency plots were assigned a binwidth of $25 \mathrm{Ma}$. KDEs were plotted using a bandwidth of $20 \mathrm{Ma}$ and a Gaussian kernel. This bandwidth was chosen by trial and error (by comparison with histograms and probability density plots) because in many cases the 'optimal bandwidth' calculated in DensityPlotter caused severe oversmoothing. More importantly, the same bandwidth was applied to all samples and to detrital zircons from potential source areas so that comparisons were like-for-like. Multi-dimensional scaling (MDS) analysis was performed using the R package provenance by Vermeesch et al. (2016).

\section{White mica $\mathrm{Ar}-\mathrm{Ar}$}

Detrital white mica Ar-Ar ages for the Coumeenoole Formation in the Dingle Group from Ennis et al. (2015) are recalculated in this study using the $28.201 \pm 0.046 \mathrm{Ma}$ age of Kuiper et al. (2008) for the Fish Canyon sanidine standard, generally increasing the age of single grains by c. $1 \%$. This was done to facilitate comparison of future detrital white mica analyses, which will be conducted using this age for the standard. Details of analytical procedures have been given by Ennis et al. (2015).

\section{Apatite $\mathrm{U}-\mathrm{Pb}$}

At each outcrop, c. $10 \mathrm{~kg}$ of material was collected across several adjacent beds to reduce any bias arising during deposition from localized heavy mineral concentrating processes. Subsequent sample preparation and analysis were conducted at Trinity College Dublin. The sub-300 $\mu \mathrm{m}$ nonmagnetic heavy mineral fraction was obtained by standard jaw crushing, sieving, magnetic and heavy liquid separation techniques. Grains were mounted in epoxy resin, ground to expose internal surfaces, and polished. To avoid sample bias, no attempt was made to exclude anhedral or inclusion-bearing grains; the LA-ICP-MS technique permits identification and exclusion of U-rich inclusions (e.g. zircon) from the time-resolved (i.e. downhole) ablation signal of the appropriate isotopes.

Analyses were conducted using a Photon Machines Analyte Excite $193 \mathrm{~nm}$ ArF excimer laser ablation system coupled to a Thermo Scientific iCAP Qc ICP-MS system, employing laser spots of $30 \mu \mathrm{m}$, a fluence of $4.5 \mathrm{~J} \mathrm{~cm}^{-2}$, a repetition rate of $5 \mathrm{~Hz}$, and an ablation time for each spot of $45 \mathrm{~s}$ followed by a $25 \mathrm{~s}$ background measurement. Repeated measurements of the primary Madagascar apatite mineral standard (Thomson et al. 2012) were used to correct for downhole $\mathrm{U}-\mathrm{Pb}$ fractionation, mass bias and intrasession instrument drift using the 'VizualAge_UcomPbine' data reduction scheme for IOLITE (Paton et al. 2011; Chew et al. 2014), and the secondary McClure Mountain and Durango apatite standards were analysed as unknowns (McDowell et al. 2005; Schoene \& Bowring 2006). Unlike phases that exclude common (initial or nonradiogenic) $\mathrm{Pb}$ during crystallization, such as zircon, the often high common- $\mathrm{Pb}$ content in apatite typically renders apatite grains discordant in the $\mathrm{U}-\mathrm{Pb}$ system. Common- $\mathrm{Pb}$ in the Madagascar apatite primary standard was corrected for using a ${ }^{207} \mathrm{~Pb}$-based correction method using a known initial ${ }^{207} \mathrm{~Pb} /{ }^{206} \mathrm{~Pb}$ ratio (Chew et al. 2014). Variable common- $\mathrm{Pb}$ content in the detrital apatite unknowns was corrected by using an initial common- $\mathrm{Pb}$ composition derived from a terrestrial $\mathrm{Pb}$ evolution model (Stacey \& Kramers 1975) applied to an initial estimate for the age of the apatite, and then by adopting an iterative approach based on $\mathrm{a}^{207} \mathrm{~Pb}$ correction (Chew et al. 2011). The ${ }^{207} \mathrm{~Pb}$-based correction assumes $\mathrm{U}-\mathrm{Pb} *$ (radiogenic $\mathrm{Pb}$ ) concordance, a reasonable assumption in the case of standards and magmatic grains, but one that may not be the case for detrital grains that have experienced partial $\mathrm{Pb}$ loss. As a result, independent geological evidence is required to discriminate between partially and wholly reset detrital $\mathrm{U}-\mathrm{Pb}$ ages, similar to partially reset AFT ages (Mark et al. 2016).

Owing to the ${ }^{207} \mathrm{~Pb}$-based correction, no apatite $\mathrm{U}-\mathrm{Pb}$ age data can be excluded based on discordance criteria. However, the relatively low $U$ content of apatite (sometimes $<1 \mathrm{ppm}$ ) and consequent near-zero radiogenic $\mathrm{Pb}$ content of some grains can result in undesirably large analytical uncertainties. We therefore excluded grains with $2 \sigma$ errors $>25 \%$, similar to the approach of Zattin et al. (2012).

As post-deposition temperatures exceeded the thermal sensitivity of the AFT technique (c. $120-60^{\circ} \mathrm{C}$; e.g. Gallagher et al. 1998), the resultant AFT ages typically defined a single population for each sample. Because only a single AFT age population was defined for each sample, it was only necessary to analyse c. 20-30 grains for each sample.

\section{Detrital zircon $\mathrm{U}-\mathrm{Th}-\mathrm{Pb}$ results}

Two hundred and seventy-three zircons were analysed from the Lower Devonian Dingle Group on the Dingle Peninsula. Another 119 detrital zircon grains were analysed from the Upper Devonian Slieve Mish Group on the Dingle Peninsula. The number of concordant ages obtained from each sample ensures an extremely low probability of missing an age component that contributes $10 \%$ of the detrital zircon age population of the analysed sediment (Vermeesch et al. 2016). For all three samples, where age populations contribute over $6 \%$, interpretations can be made at the 95\% confidence level. 
Age uncertainties reported in the text are at the $2 \sigma$ level unless otherwise stated. Core-rim analyses were undertaken where these features could be identified in CL images and where grains were large enough. Only rim ages are used for provenance interpretations in order to determine the most recent source of sediment. The results are presented as Wetherill concordia (Wetherill 1956), frequency and KDE plots (Figs 4 and 5 ). The ${ }^{207} \mathrm{~Pb} /{ }^{206} \mathrm{~Pb}$ age is reported where the ${ }^{206} \mathrm{~Pb} /{ }^{238} \mathrm{U}$ age is greater than $1.0 \mathrm{Ga}$ because the ${ }^{207} \mathrm{~Pb} /{ }^{206} \mathrm{~Pb}$ age is more precise in older zircon grains (e.g. Gehrels et al. 2008).
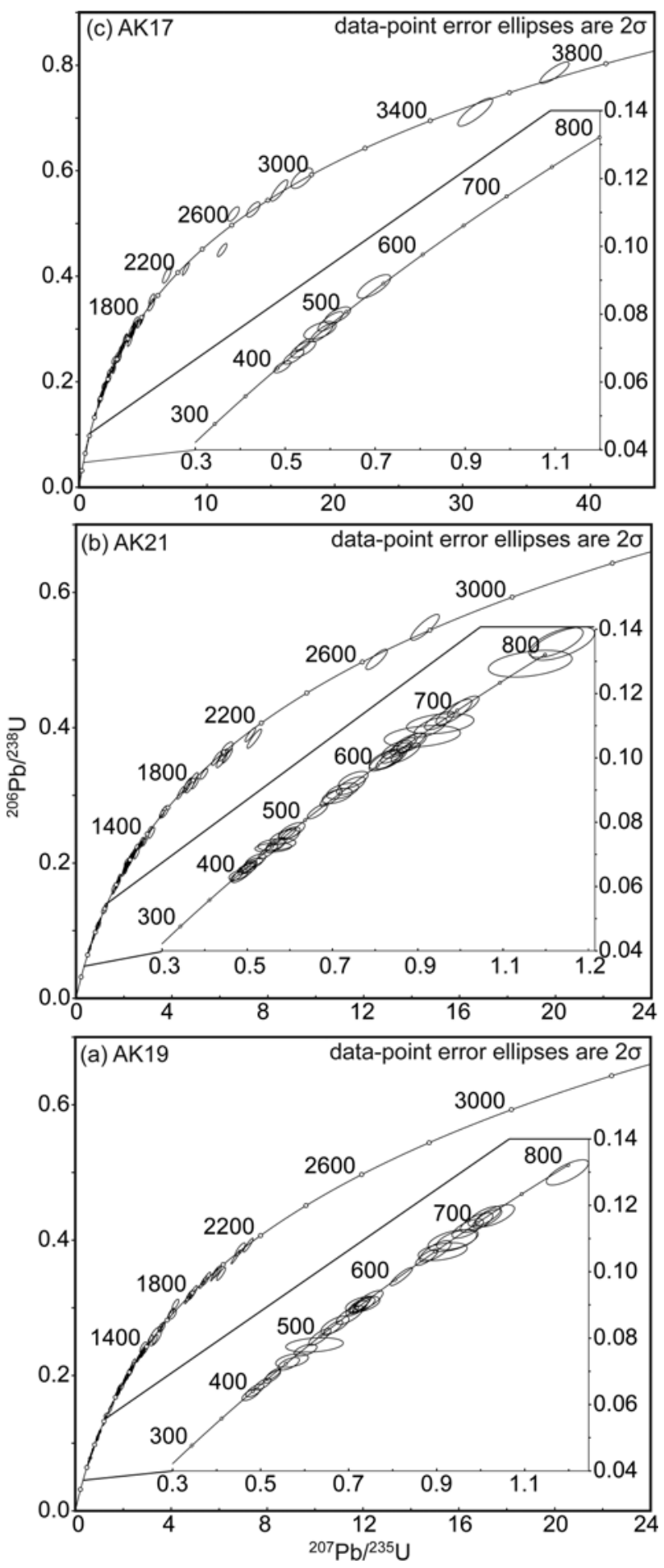

Fig. 4. Wetherill concordia plots for all detrital zircon samples analysed in this study (youngest ages inset). (a) Coumeenoole Formation (sample AK19). (b) Slea Head Formation (sample AK21). (c) Cappagh Sandstone Formation (sample AK17).

\section{Coumeenoole Formation, sample AK19}

Sample AK19, collected at Connor Pass, consists of grey, moderately sorted, medium- to coarse-grained sandstone and is the stratigraphically oldest sample in the study area. One hundred and fourteen zircon grains were analysed yielding a total of 86 concordant analyses ranging from $394 \pm 9$ to $2142 \pm 16 \mathrm{Ma}$ (Fig. 4a). Thirty-seven grains (43\%) yielded Mesoproterozoic ages, which form a major peak at around $1.20 \mathrm{Ga}$ (Fig. 5a). Neoproterozoic zircons make up 26\% $(n=22)$ of the sample, the second largest peak in the sample occurring at around $550 \mathrm{Ma}$. The rest of the sample is composed of 14 (16\%) Paleoproterozoic zircons and $13(15 \%)$ Paleozoic zircons. Of the Paleozoic grains, four are Cambrian, four are Ordovician, two are Silurian and three are Devonian. Two of the Devonian zircons, the youngest in the sample, have ages of $394 \pm 9$ and $402 \pm 10 \mathrm{Ma}$ and have length:width ratios of 3:1 and 5:1 respectively. Kostov (1973) suggested that high length:width ratios may indicate rapid cooling rates. However, such ratios may simply represent first-order detrital zircons that have not been reworked (Poldervaart 1955).

\section{Slea Head Formation, sample AK21}

This sample was taken from Cooleen Pier in Ventry Bay and consists of dark grey, medium- to coarse-grained, pebbly sandstones. Ninety-eight concordant ages were obtained from measurement of 159 zircon grains. Ages range from $395 \pm 8$ to $2765 \pm 29 \mathrm{Ma}$ and the largest peak is developed at $1.18 \mathrm{Ga}$ (Figs $4 \mathrm{~b}$ and $5 \mathrm{~b}$ ). Mesoproterozoic zircons form the bulk of the sample at $40 \%(n=39)$. Twenty-six zircon grains $(27 \%)$ are Neoproterozoic in age, forming a major peak at c. $630 \mathrm{Ma}$. Paleoproterozoic zircons contribute $13 \%(n=13)$ of the sample. Eighteen grains are Paleozoic in age, including one Cambrian zircon, eight Ordovician zircons, three Silurian zircons and six Devonian zircons. This sample, unlike AK19, also contains Archean grains $(n=2)$. A concordia age of $405 \pm 4 \mathrm{Ma}\left(\mathrm{MSWD}_{\mathrm{conc}}=0.18\right.$; $\left.p_{\text {conc }}=0.67\right)$ was calculated using the six Devonian zircons. Two of these zircons display length:width ratios of greater than $3: 1$.

\section{Cappagh Sandstone Formation, sample AK17}

This sample, consisting of grey to pink, poorly sorted medium- to coarse-grained, pebbly sandstone, was taken from a ridge cropping out at Aughils, north of the R561. One hundred and nineteen zircons were analysed, producing 84 concordant ages ranging from $403 \pm 9$ to $3677 \pm 21 \mathrm{Ma}$ (Fig. 4c). The majority of these grains are Mesoproterozoic in age (43 grains representing 51\% of the sample) and the largest peak in the sample is Mesoproterozoic at c. $1.05 \mathrm{Ga}$ (Fig. 5c). Sixteen grains $(19 \%)$ are Paleoproterozoic in age and represent the second largest population in the sample. Neoproterozoic zircons represent $12 \%(n=10)$ of the sample. Paleozoic zircons represent $10 \%$, including one Cambrian zircon, three Ordovician zircons, three Silurian zircons and one Devonian zircon. Seven Archean zircon grains are present in the sample. There is a paucity of zircon ages $(n=3)$ between $c .550$ and $c$. $980 \mathrm{Ma}$.

\section{Apatite $\mathrm{U}-\mathrm{Pb}$ and mica ${ }^{40} \mathrm{Ar} /{ }^{39} \mathrm{Ar}$ geochronology Apatite $\mathrm{U}-\mathrm{Pb}$}

These data were generated concurrently with apatite fission-track analyses that were undertaken for bedrock thermal history studies by Cogné et al. (2014), but were not previously published. Because of the low number of detrital apatite grains analysed, the data must be interpreted with caution. In some cases, samples from the same formation are combined to yield the minimum statistical requirement of 60 analyses, in accordance with Dodson et al. (1988). The 


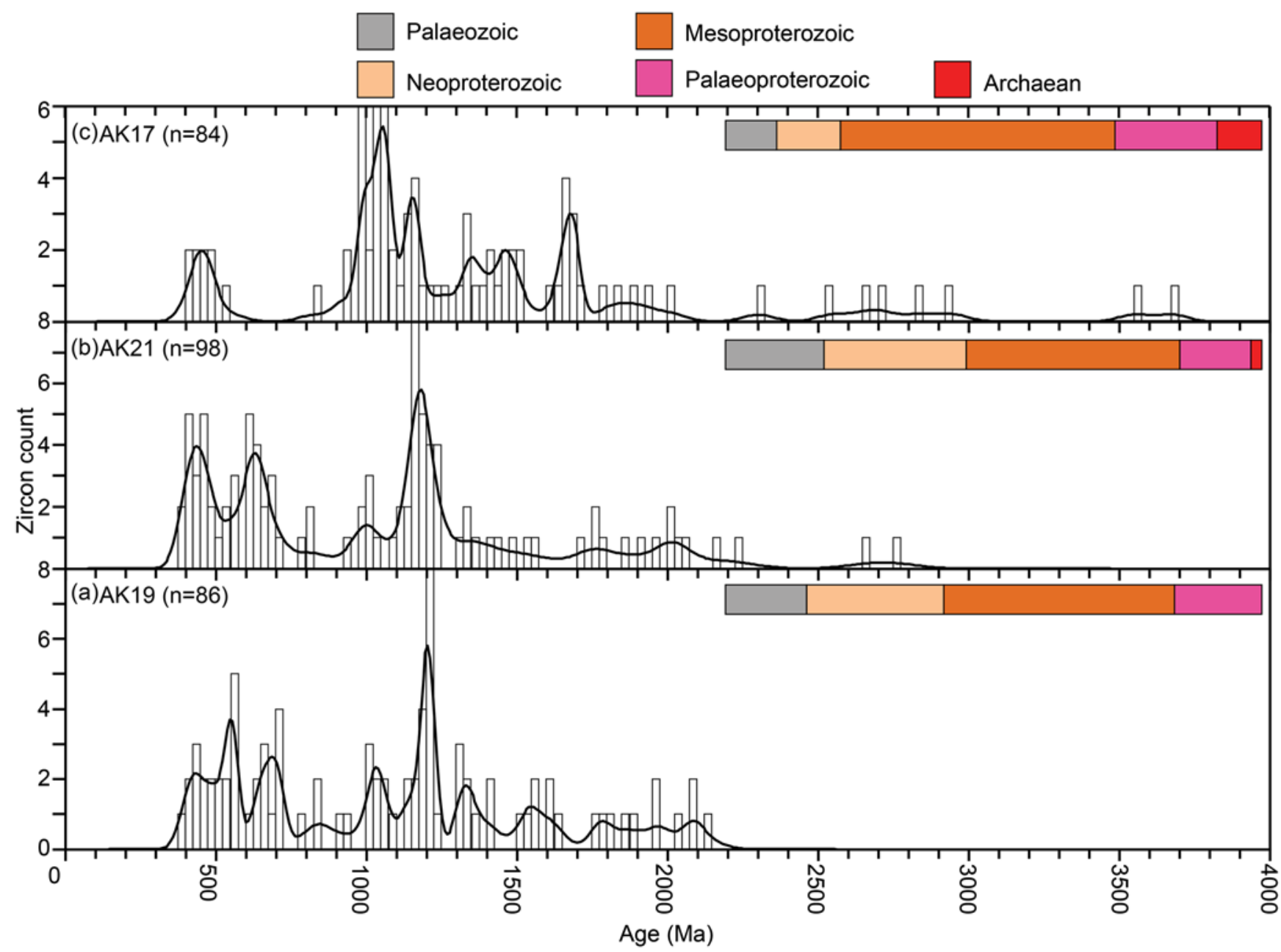

Fig. 5. Detrital zircon age KDE, histogram plots and age percentage distribution plots from Dingle Peninsula samples. (a) Coumeenoole Formation (sample AK19). (b) Slea Head Formation (sample AK21). (c) Cappagh Sandstone Formation (sample AK17).

limited variability in detrital apatite ages in these larger samples suggests that it is unlikely that multiple apatite sources of significantly different age and thermal history were being sampled by the sediments under investigation. The apatite $\mathrm{U}-\mathrm{Pb}$

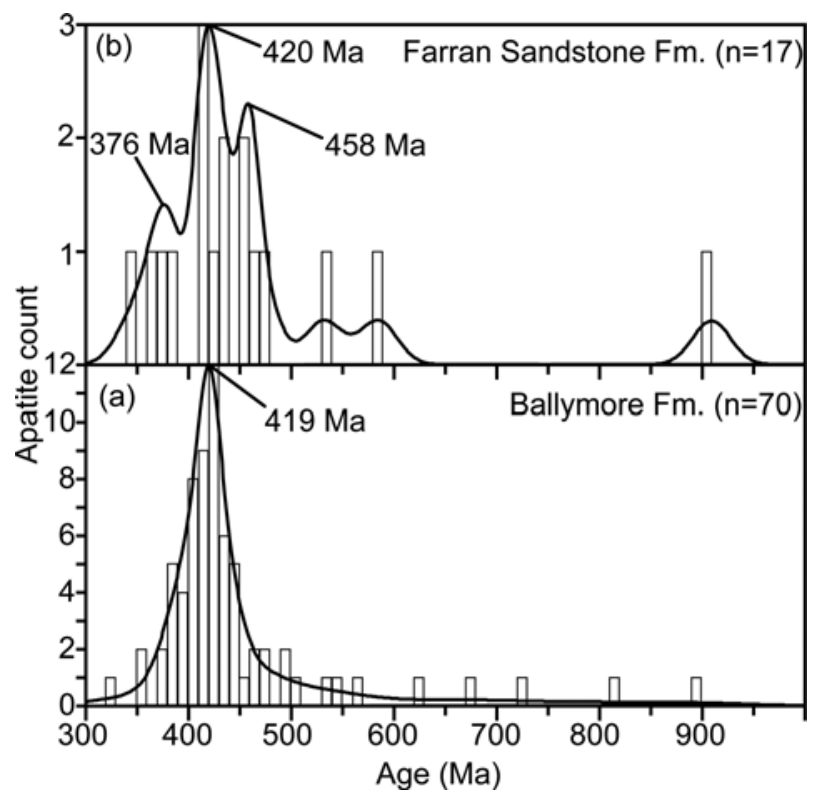

Fig. 6. KDE and histogram plots for detrital apatite $\mathrm{U}-\mathrm{Pb}$ ages in (a) the Ballymore Formation and (b) the Farran Sandstone Formation. ages were not utilized in the aforementioned study. Therefore the data have been included in this study (Fig. 6) to provide a geochronological proxy that has an intermediate closure temperature (c. $375-550^{\circ} \mathrm{C}$; Cochrane et al. 2014) between the mica ${ }^{40} \mathrm{Ar} /{ }^{39} \mathrm{Ar}$ and zircon $\mathrm{U}-\mathrm{Pb}$ systems. The sampling transect was collected from Mount Brandon on the Dingle Peninsula (Fig. 3). This transect intersected two formations and includes four samples taken from the Ballymore Sandstone Formation and one sample from the Farran Sandstone Formation.

Combined analyses from four samples (Mb-1, Mb-4, Mb-5 and $\mathrm{Mb}-7)$ from the Ballymore Sandstone Formation, the uppermost formation in the Dingle Group, yields a KDE spectrum composed of 70 ages forming a single KDE peak at c. $420 \mathrm{Ma}$. Detrital apatite ages in this formation range from $356 \pm 80$ to $896 \pm 30 \mathrm{Ma}$ (Fig. 6a). However, $63 \%$ of grains have ages between 380 and $440 \mathrm{Ma}$ and $10 \%$ have ages of less than $393 \mathrm{Ma}$ (end-Emsian). Eighteen apatite grains were analysed from the Farran Sandstone Formation (sample Mb-9), the lowest formation in the Smerwick Group. These grains range in age from $347 \pm 58$ to $1356 \pm 227 \mathrm{Ma}$. The KDE spectrum (Fig. 6b) shows the highest age concentration at c. $420 \mathrm{Ma}$.

$\operatorname{Mica}^{40} \mathrm{Ar}{ }^{39} \mathrm{Ar}$

Ennis et al. (2015) acquired detrital white mica ages for a sample from the Coumeenoole Formation, at a similar location (Connor Pass) to detrital zircon sample AK19. These ages have been recalculated here using the revised Fish Canyon standard age of Kuiper et al. (2008). Detrital white mica ages in the sample range 


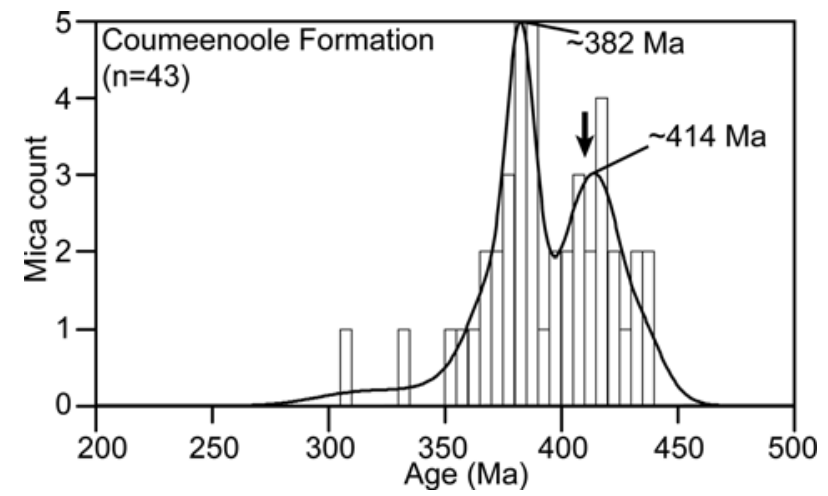

Fig. 7. Histogram and KDE plot of revised detrital white mica ages from a sample from the Coumeenoole Formation at Connor Pass on the Dingle Peninsula (original data from Ennis et al. 2015). Bold arrow represents approximate depositional age (see text for explanation of 382 Ma peak).

from $308 \pm 10.3$ to $440 \pm 7 \mathrm{Ma}$, including two main age groups forming $\mathrm{KDE}$ peaks at c. 414 and c. $382 \mathrm{Ma}$ (Fig. 7).

\section{Discussion}

The overall age distribution of detrital zircons in samples from the Coumeenoole and Slea Head formations (similar Proterozoic distributions, a gap in ages between 730 and $940 \mathrm{Ma}$, mostly continuous distributions between 390 and $730 \mathrm{Ma}$ and major KDE peaks at around $1.2 \mathrm{Ga}$ ) suggests a common source throughout their deposition (Kolmogorov-Smirnov test $P$-value of 0.871 ). Paleozoic peaks in both samples, at around $430 \mathrm{Ma}$, probably correspond to a Caledonian (430-420 Ma) source. A mean ${ }^{207} \mathrm{~Pb} /{ }^{206} \mathrm{~Pb}$ age of $432 \pm 3 \mathrm{Ma}$ as well as a whole-rock $\mathrm{Rb}-\mathrm{Sr}$ isochron age of $428 \pm 11 \mathrm{Ma}$ was obtained by O'Connor et al. (1988) for the Carnsore granite. A Rb-Sr whole-rock isochron age of $436 \pm 7$ Ma for the Saltees granite obtained by Max et al. (1979) led O'Connor et al. (1988) to conclude that the two intrusions are genetically related. These intrusions are the only ones of this age in Ireland and the $430 \mathrm{Ma}$ age of detrital zircons from the Lower Old Red Sandstone, as well as the northerly directed palaeoflow of the Trabeg Conglomerate Formation (Todd 2000), suggests that the intrusions extend westward beneath the Munster Basin along the strike of Caledonian lineaments. The idea of such a buried granite is not new; it was first proposed by Murphy (1960) and has since been expanded upon by a number of researchers (e.g. Ford et al. 1991; Meere 1995; Masson et al. 1998; Todd 2000; Vermeulen et al. 2000). Vermeulen et al. (2000) interpreted seismic profiles across southern Ireland as showing a shallow granitic body buried beneath the Upper Old Red Sandstone just south of the Killarney-Mallow Fault Zone. Todd (2000) suggested that granite clasts within the Trabeg Conglomerate Formation might represent the unroofing of an at present buried granitic intrusion that forms part of an extension of the Leinster Massif.

Detrital apatite ages from the uppermost part of the Dingle Group, in the Ballymore Formation, yield a single peak at c. $420 \mathrm{Ma}$ (Fig. 6a), which is compatible with a Late Caledonian granitic source. Williams et al. (1999) obtained an age of $411 \mathrm{Ma}$ for the Cooscrawn Tuff Bed in the Ballymore Formation, which is older than 22 of the 70 detrital apatites analysed in this formation. A concordia age from six zircons in the underlying Slea Head Formation provides a minimum depositional age of $405 \pm 4 \mathrm{Ma}$ $\left(\mathrm{MSWD}_{\text {conc }}=0.18 ; p_{\text {conc }}=0.67\right)$ and suggests that the Cooscrawn Tuff age is probably erroneous. Palynological evidence places the deposition of the Slea Head Formation in early to possibly middle Emsian times and is compatible with the youngest group of detrital zircons in this formation. The high length:width ratio of some of the youngest zircons in both the Coumeenoole and Slea Head formations may suggest an igneous source that had cooled rapidly (Kostov 1973), possibly a synsedimentary volcanic source. Although U-Pb ages of apatite grains from the Ballymore Formation are younger, they are nonetheless indistinguishable from the zircon ages of the Coumeenoole and Slea Head formations at the $2 \sigma$ level. A dominant age peak of c. $420 \mathrm{Ma}$ (Fig. 6b) is also observed for 17 detrital apatite grains in the Farran Sandstone Formation (Smerwick Group), which unconformably overlies the Ballymore Formation.

An early Paleozoic source of detrital mica is reflected in the oldest age peak (c. 414 Ma, Fig. 7) from a sample from the Coumeenoole Formation. However, the dominant age peak is much younger, at $c$. $382 \mathrm{Ma}$. This peak is much younger than the Emsian depositional age of the host sedimentary rock and suggests that the Lower Old Red Sandstone experienced a thermal resetting event. A review of the potential causes of resetting has been provided by Ennis et al. (2015) and the extension associated with Lough Guitane volcanism in the Munster Basin was briefly mentioned. Given that Williams et al. (2000) obtained a U-Pb zircon age of 378.5 Ma for the Horses Glen Volcanic Centre and 384.5 Ma for the Killeen Volcanic Centre (which lie to the SE of the Dingle Basin), it is likely that the younger detrital mica ages represent resetting by high heat flow associated with extension and volcanism, which may have been caused by emplacement of a granitic body at depth below the Munster Basin (Avison 1984). Alternatively, these younger ages could represent partial resetting owing to low-grade Variscan metamorphism at the end of the Carboniferous Period.

The low proportion of Paleozoic zircons in the Dingle Group does not reflect the high proportion of volcanic clasts reported by Todd (2000) and interpreted to have been derived from rocks of Ordovician to Silurian age. This, however, may simply be a function of low zircon fertility in the volcanic source owing to the dominant mafic to intermediate compositions (Todd 2000).

Determination of the ultimate source of late Neoproterozoic detrital zircons in these samples is relatively straightforward because of the lack of abundant known sources of this age on this part of the Laurentian craton (Fig. 2). The Lower Old Red Sandstone samples also contain some 1.9-2.1 Ga zircons, considered to be indicative of the Gondwanan Eburnean Orogeny (Nance et al. 2008). Late Neoproterozoic zircons are ubiquitous in periGondwanan terranes as a result of arc magmatism at that time (Nance et al. 2008) and therefore represent the most likely source. It should be noted, however, that Cawood \& Nemchin (2001) reported extensional magmatism associated with rifting in Laurentia between 520 and $555 \mathrm{Ma}$. But sedimentary rocks interpreted to be of Laurentian affinity do not record extensive Neoproterozoic zircon production (Fig. 2). Combined detrital zircon ages from various Cambrian formations in the Leinster Massif (Waldron et al. 2014) yield a high proportion in the range 500-770 Ma forming a peak at around $590 \mathrm{Ma}$ (Fig. 8d). Waldron et al. (2014) proposed that these zircon ages represent a Ganderian source for the host sediments. If the source of granitic material for the Dingle Group was indeed Late Caledonian granites as suggested above, then, by extension, the Cambrian to Ordovician rocks into which the granites intrude are also a viable source of detritus. Support for derivation of late Neoproterozoic zircons from recycling of peri-Gondwanan sediments can be found in the study by Todd (2000), who found coticule and tourmalinite clasts akin to rocks found in the Ordovician Ribband Group. Todd (2000) also suggested that quartzite clasts in the Trabeg Conglomerate Formation could be related to quartzites of the Cambrian Bray Group. The similarity in the ranges of detrital zircon ages younger than $800 \mathrm{Ma}$ in both the Coumeenoole and Slea Head formations suggests that this southerly source remained available throughout their deposition.

Zircons with ages in the range of 1.1-1.25 Ga, the most abundant in both samples, are probably ultimately sourced from Laurentia. 


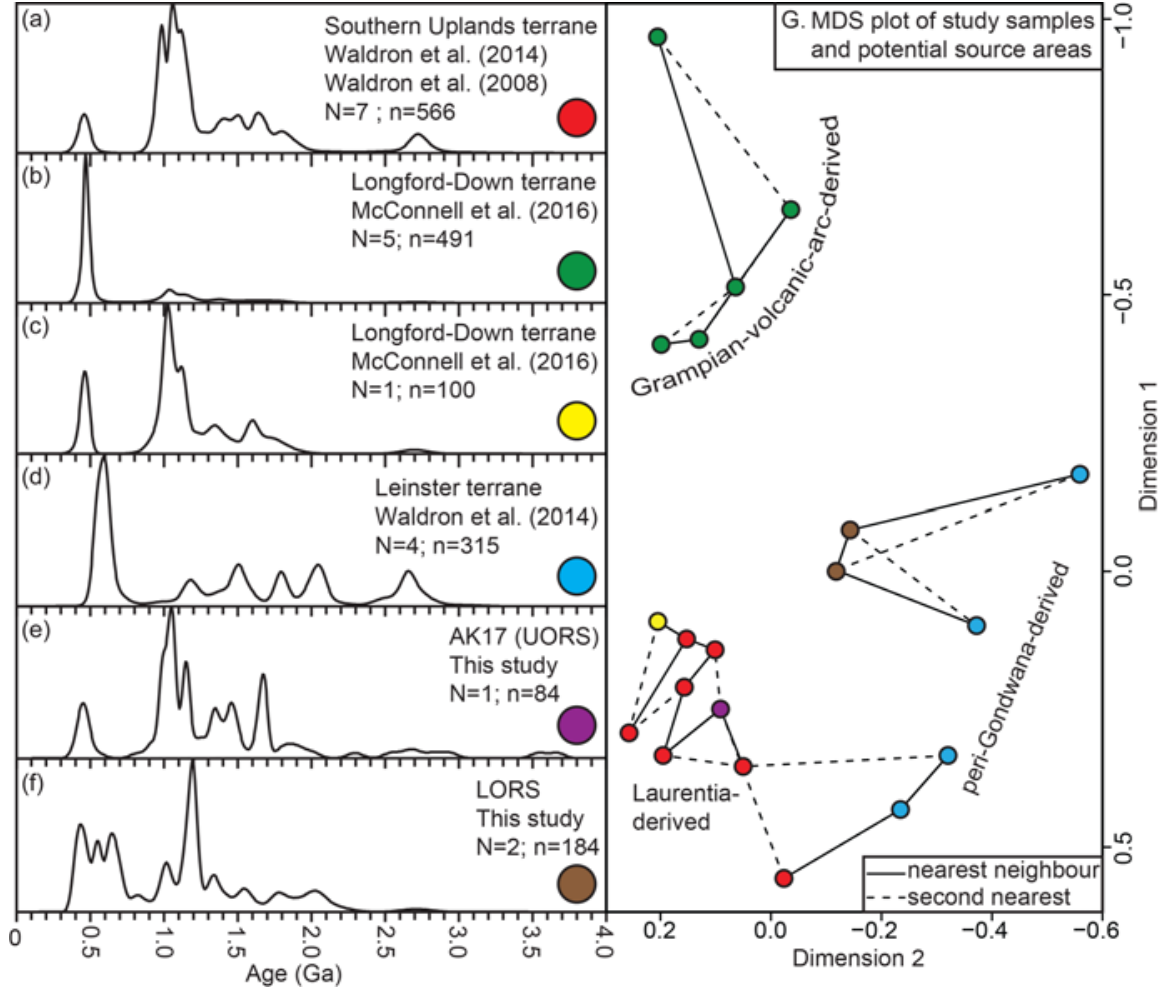

Fig. 8. KDE plots of detrital zircon ages from various potential local sediment sources as well as age distributions for detrital zircons analysed in this study. (a) Upper Ordovician to Llandovery sedimentary rocks of the Southern Uplands terrane (Waldron et al. 2008, 2014) with dominant Laurentian provenance. (b) Upper Ordovician to Llandovery sedimentary rocks of the Longford Down terrane showing periLaurentian arc provenance (McConnell et al. 2016). (c) A single sample from the Llandovery Lough Avaghon Formation in the Longford Down terrane showing dominant Laurentian provenance (McConnell et al. 2016). (d) Ganderian provenance of Cambrian sedimentary rocks in the Leinster terrane (Waldron et al. 2014). (e) Upper Old Red Sandstone (UORS) on the Dingle Peninsula.

(f) Composite of two samples from the Lower Old Red Sandstone (LORS) Dingle Group. (g) Multi-dimensional scaling map of single samples used in plots (a)-(f). Labels indicate broad provenance interpretations from original studies. Axis values are $\mathrm{K}-\mathrm{S}$ effect sizes (Vermeesch 2013). The most closely related samples are joined by a continuous line and the second closest are marked with a dashed line. $N$, number of samples; $n$, number of single zircon grain ages.
Cawood \& Nemchin (2001) considered grains in this age range to be representative of magmatic and metamorphic activity associated with the Grenville Orogeny. Zircons of similar age are present in the Ganderia-derived Cambrian sediments in the Leinster Massif. However, the far greater abundance of zircons of this age range relative to zircons of late Neoproterozoic age in the Dingle Group samples requires an additional source from which the older zircons can be derived.

Constructing a palaeodrainage pattern for the Coumeenoole and Slea Head formations requires a source (or sources) of detritus that meets the following criteria: (1) abundant zircons yielding $c .1 .2 \mathrm{Ga}$ $\mathrm{U}-\mathrm{Pb}$ ages (probably of ultimate Laurentian affinity); (2) presence of late Neoproterozoic and 1.9-2.1 Ga zircons (of peri-Gondwanan affinity); (3) paucity of zircons between 730 and $940 \mathrm{Ma}$; (4) low proportion of Paleozoic zircons; (5) Late Caledonian apatite $\mathrm{U}-\mathrm{Pb}$ and white mica ${ }^{40} \mathrm{Ar} /{ }^{39} \mathrm{Ar}$ ages (c. 420 and $414 \mathrm{Ma}$, respectively).
Transverse drainage, as indicated by palaeocurrent directions (Todd 2000), particularly from the south but possibly also from the north, was the likely means by which Late Caledonian and periGondwanan material was supplied to the Dingle Basin (Fig. 9). Evidence of Late Caledonian detrital input to the basin is given by $420 \mathrm{Ma}$ apatite and $414 \mathrm{Ma}$ mica ages. Although the ultimate source of Mesoproterozoic zircons in the Coumeenoole and Slea Head formations was probably the Grenville Orogeny, defining the immediate source area is more problematic because a source of abundant $1.2 \mathrm{Ga}$ zircons has not been found in Ireland. Ordovician and Silurian sediments from the Southern Uplands-Longford Down terrane show an abundance of $1.1 \mathrm{Ga}$ (Fig. 8a and c) and Ordovician zircons (Fig. 8b). This accretionary wedge material is therefore a poor candidate unless the source character of these sedimentary rocks changes westward, along-strike. The apparent dissimilarity, revealed by multi-dimensional scaling analysis, between the Dingle

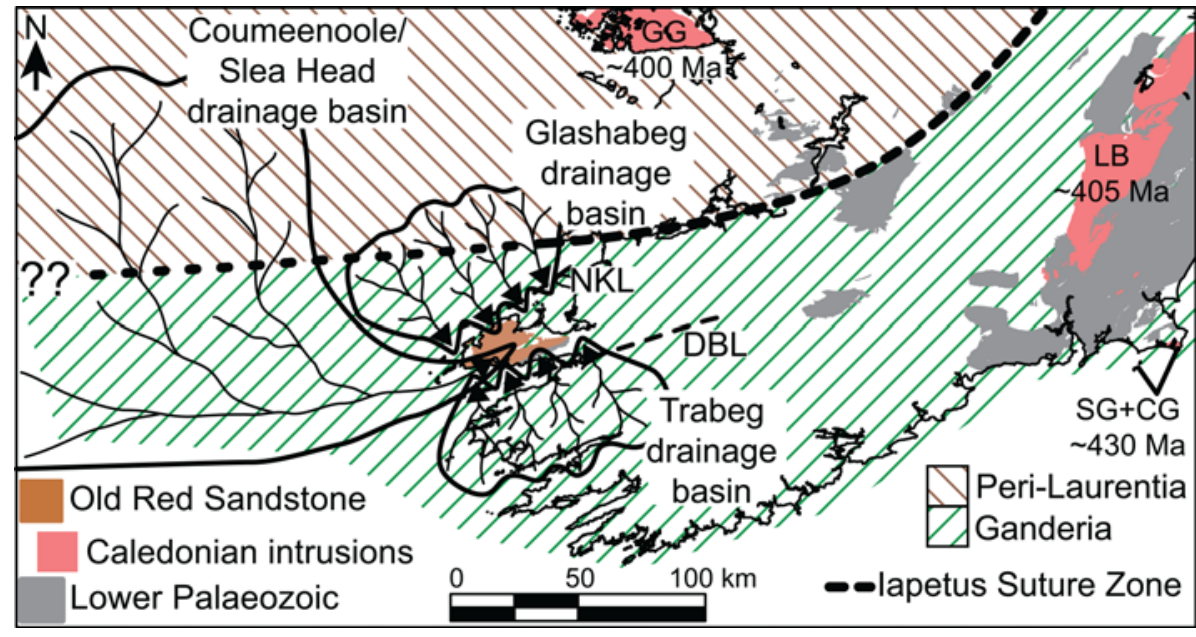

Fig. 9. Possible palaeodrainage pattern in the Dingle basin during deposition of the Coumeenoole and Slea Head formations (modified after Todd 2000). CG, Carnsore Granite; DBL, Dingle Bay Lineament; GG, Galway Granite Batholith; LB, Leinster Batholith; NKL, North Kerry Lineament; SG, Saltees Granite. 
Group samples and samples of Laurentian derivation in the Southern Uplands-Longford Down terrane (Fig. 8g) reflects the lack of $1.2 \mathrm{Ga}$ zircons in the available source data and presence of late Neoproterozoic zircons of peri-Gondwanan affinity in the Dingle Group samples.

Given the bulk northeastward palaeoflow in the Coumeenoole and Slea Head formations (Todd et al. 1988), it is likely that most of the detritus was deposited as a result of this flow. A source to the SW of the Dingle Basin must account for the high proportion of Laurentian zircons in the analysed samples. Therefore, although the main river course probably flowed from the west and SW, we suggest that Caledonian highlands in the north produced a large number of tributaries flowing from north to south, into the main CoumeenooleSlea Head system (Fig. 9). Alternatively, it is also possible that the Iapetus Suture forms a regional S-shape and that the strike of the suture swings from roughly east-west onshore to SW-NE off the SW coast of Ireland. This is highly speculative, however, as there is no other supporting evidence for such a hypothesis.

Unlike the Lower Old Red Sandstone on the Dingle Peninsula, the Upper Old Red Sandstone, represented by sample AK17 from the Cappagh Sandstone Formation, contains very few late Neoproterozoic zircons but is instead dominated by Mesoproterozoic grains. Also unlike the Lower Old Red Sandstone, the Upper Old Red Sandstone contains a dominant $1.05 \mathrm{Ga}$ peak as opposed to the $1.2 \mathrm{Ga}$ peak of the Lower Old Red Sandstone. The lack of late Neoproterozoic grains, dominant $1.05 \mathrm{Ga} \mathrm{KDE}$ peak and similarity to detrital zircon age spectra of Laurentian affinity (Fig. 8a, c and g) indicates a northerly derived source area and no input from sources south of the Iapetus Suture. It would also indicate that recycling of the Lower Old Red Sandstone into the Upper Old Red Sandstone in southern Ireland, as previously suggested, is not likely to have occurred. It is more conceivable that this sediment was recycled from material similar to that found in the Longford Down terrane.

It is becoming widely accepted that a period of regional sinistral transtension occurred across the Iapetus Suture Zone in the Early Devonian Period (Todd 1989; Phillips et al. 1995; Dewey \& Strachan 2003; Brown et al. 2008; Cooper et al. 2016). In the present study, the discrepancy between $1.2 \mathrm{Ga}$ Laurentian zircons found in the Dingle Group and 1.1 Ga Laurentian zircons found in the Longford Down and Southern Uplands terranes, as well as the abundance of $1.05 \mathrm{Ga}$ zircons in the Upper Old Red Sandstone of the Dingle Peninsula, is supportive of large-scale sinistral transtensional displacement along the Iapetus Suture, removing the $1.2 \mathrm{Ga}$ source of detrital zircon and introducing the 1.05-1.1 Ga source to the Upper Old Red Sandstone in the Late Devonian Period. Of course, this discrepancy may not have tectonic significance and may simply be representative of topographic separation of sources or complete denudation of the $1.2 \mathrm{Ga}$ source and subsequent exhumation of the $1.1 \mathrm{Ga}$ source. High-resolution detrital zircon sampling of younger formations within and overlying the Dingle Group would serve to elucidate the nature and timing of the change in source character. Finally, a minimum depositional age of c. $405 \mathrm{Ma}$ for the Coumeenoole Formation adds to growing evidence (Soper \& Woodcock 2003, and references therein) of a discrete Emsian orogenic event in the British Isles.

\section{Conclusions}

This paper presents the first multi-proxy, single-grain detrital geochronological study of the Lower Old Red Sandstone in the Early Devonian Dingle Basin in SW Ireland, which suggests the following.

(1) The Dingle Basin sedimentary fill is dominated by Laurentian detritus but also includes a mixture of peri-
Gondwanan and Late Caledonian (430-420 Ma) to Acadian (410-390 Ma) source areas.

(2) A dominant drainage area lay to the west but the basin must have received much detritus from transverse drainage to the north, which intersected Laurentian material.

(3) Detrital zircons from the Upper Old Red Sandstone Cappagh Sandstone Formation demonstrate only a Laurentian source of sediment in contrast to the mixed source observed in the Lower Old Red Sandstone.

(4) The paucity of late Neoproterozoic zircons in the Upper Old Red Sandstone compared with the high proportion in the Lower Old Red Sandstone suggests that the Upper Old Red Sandstone was not derived from recycling of Lower Old Red Sandstone sediments as previously suggested.

(5) Well-documented regional sinistral transtension during the Early Devonian Period was probably responsible for a switch in Laurentian source character from the Lower Old Red Sandstone (prevalence of 1.2 Ga detrital zircons) to the Upper Old Red Sandstone (prevalence of 1.1 Ga detrital zircons).

Acknowledgements D. Pastor-Galan is thanked for his geochronology and sampling advice. C. Reid and R. van Elsas are thanked for their technical assistance for SEM and sample preparation respectively. J. W. F. Waldron and J. F. Dewey are thanked for their constructive reviews, which significantly improved the paper.

Funding B.J.F., A.K., P.A.M. and K.F.M. acknowledge the financial support of the Irish Shelf Petroleum Studies Group (ISPSG) of the Irish Petroleum Infrastructure Programme (PIP) Group 4 (project code IS 12/05 UCC). The ISPSG comprises Atlantic Petroleum (Ireland) Ltd, Cairn Energy Plc, Chrysaor E\&P Ireland Ltd, Chevron North Sea Limited, ENI Ireland BV, Europa Oil \& Gas, ExxonMobil E\&P Ireland (Offshore) Ltd, Husky Energy, Kosmos Energy LLC, Maersk Oil North Sea UK Ltd, Petroleum Affairs Division of the Department of Communications, Energy and Natural Resources, Providence Resources Plc, Repsol Exploración SA, San Leon Energy Plc, Serica Energy Plc, Shell E\&P Ireland Ltd, Sosina Exploration Ltd, Tullow Oil Plc and Woodside Energy (Ireland) Pty Ltd. D.C., C.M. and N.C. acknowledge support from Science Foundation Ireland grants 12/IP/1663 and 13/RC/2092 (iCRAG Research Centre, project HC4.2PD6a). iCRAG is funded under the SFI Research Centres Programme and is co-funded under the European Regional Development Fund. K.F.K. acknowledges financial support of NWO grant 864.12.005.

\section{Scientific editing by Anna Bird}

\section{References}

Avison, M. 1984. The Lough Guitane Volcanic Complex, County Kerry: a preliminary survey. Irish Journal of Earth Sciences, 6, 127-136.

Barr, S.M., Davis, D.W., Kamo, S. \& White, C.E. 2003. Significance of U-Pb detrital zircon ages in quartzite from peri-Gondwanan terranes, New Brunswick and Nova Scotia, Canada. Precambrian Research, 126, 123-145, https://doi.org/10.1016/S0301-9268(03)00192-X

Barr, S.M., Hamilton, M.A., Samson, S.D., Satkoski, A.M. \& White, C.E. 2012 Provenance variations in northern Appalachian Avalonia based on detrital zircon age patterns in Ediacaran and Cambrian sedimentary rocks, New Brunswick and Nova Scotia, Canada. Canadian Journal of Earth Sciences, 49, 533-546, https://doi.org/10.1139/e11-070

Boyd, J.D. \& Sloan, R.J. 2000. Initiation and early development of the Dingle Basin, SW Ireland, in the context of the closure of the Iapetus Ocean. In: Friend, P.F. \& Williams, B.P.J. (eds) New Perspectives on the Old Red Sandstone. Geological Society, London, Special Publications, 180, 123-145, https://doi.org/10.1144/GSL.SP.2000.180.01.08

Brown, P.E., Ryan, P.D., Soper, N.J. \& Woodcock, N.H. 2008. The Newer Granite problem revisited: a transtensional origin for the Early Devonian Trans-Suture Suite. Geological Magazine, 145, 235-256, https://doi.org/10. 1017/S0016756807004219

Cawood, P.A. \& Nemchin, A.A. 2001. Paleogeographic development of the east Laurentian margin: Constraints from U-Pb dating of detrital zircons in the Newfoundland Appalachians. Geological Society of America Bulletin, 113, 1234-1246, https://doi.org/10.1130/0016-7606(2001)113<1234:PDOTEL>2. $0 . \mathrm{CO} ; 2$

Cawood, P.A., Nemchin, A.A., Smith, M. \& Loewy, S. 2003. Source of the Dalradian Supergroup constrained by $\mathrm{U}-\mathrm{Pb}$ dating of detrital zircon and implications for the East Laurentian margin. Journal of the Geological Society, London, 160, 231-246, https://doi.org/10.1144/0016-764902-039

Cawood, P.A., Nemchin, A.A., Strachan, R., Prave, T. \& Krabbendam, M. 2007. Sedimentary basin and detrital zircon record along East Laurentia and Baltica 
during assembly and breakup of Rodinia. Journal of the Geological Society, London, 164, 257-275, https://doi.org/10.1144/0016-76492006-115

Cawood, P.A., Merle, R.E., Strachan, R.A. \& Tanner, P.W.G. 2012. Provenance of the Highland Border Complex: constraints on Laurentian margin accretion in the Scottish Caledonides. Journal of the Geological Society, London, 169, 575-586, https://doi.org/10.1144/0016-76492011-076

Chew, D.M. \& Donelick, R.A. 2012. Combined apatite fission track and U-Pb dating by LA-ICP-MS and its application in apatite provenance analysis. In: Sylvester, P.J. (ed.) Quantitative Mineralogy and Microanalysis of Sediments and Sedimentary Rocks. Mineralogical Association of Canada, Short Course Series, 42, 219-247.

Chew, D.M. \& Stillman, C.J. 2009. Late Caledonian orogeny and magmatism. In: Holland, C.H. \& Sanders, I.S. (eds) The Geology of Ireland. Dunedin Academic Press, Edinburgh, 143-174.

Chew, D.M. \& Strachan, R.A. 2014. The Laurentian Caledonides of Scotland and Ireland. In: Corfu, F., Gasser, D. \& Chew, D.M. (eds) New Perspectives on the Caledonides of Scandinavia and Related Areas. Geological Society, London, Special Publications, 390, 45-91, https://doi.org/10.1144/SP390.16

Chew, D.M., Graham, J.R. \& Whitehouse, M.J. 2007. U-Pb zircon geochronology of plagiogranites from the Lough Nafooey (= Midland Valley) arc in western Ireland: constraints on the onset of the Grampian orogeny. Journal of the Geological Society, London, 164, 747-750, https://doi.org/10.1144/001676492007-025

Chew, D.M., Sylvester, P.J. \& Tubrett, M.N. 2011. U-Pb and Th-Pb dating of apatite by LA-ICPMS. Chemical Geology, 280, 200-216, https://doi.org/10. 1016/j.chemgeo.2010.11.010

Chew, D.M., Petrus, J.A. \& Kamber, B.S. 2014. U-Pb LA-ICPMS dating using accessory mineral standards with variable common $\mathrm{Pb}$. Chemical Geology, 363, 185-199, https://doi.org/10.1016/j.chemgeo.2013.11.006

Cochrane, R., Spikings, R.A. et al.. 2014. High temperature $\left(>350^{\circ} \mathrm{C}\right)$ thermochronology and mechanisms of $\mathrm{Pb}$ loss in apatite. Geochimica et Cosmochimica Acta, 127, 39-56, https://doi.org/10.1016/j.gca.2013.11.028

Cocks, L.R.M., McKerrow, W.S. \& Van Staal, C.R. 1997. The margins of Avalonia. Geological Magazine, 134, 627-636.

Cogné, N., Chew, D. \& Stuart, F.M. 2014. The thermal history of the western Irish onshore. Journal of the Geological Society, London, 171, 779-792, https://doi. org/10.1144/jgs2014-026

Collins, A.S. \& Buchan, C. 2004. Provenance and age constraints of the South Stack Group, Anglesey, UK: U-Pb SIMS detrital zircon data. Journal of the Geological Society, London, 161, 743-746, https://doi.org/10.1144/0016764904-036

Cooper, M.R., Crowley, Q.G. et al.. 2011. Age constraints and geochemistry of the Ordovician Tyrone Igneous Complex, Northern Ireland: implications for the Grampian orogeny. Journal of the Geological Society, London, $\mathbf{1 6 8}$, 837-850, https://doi.org/10.1144/0016-76492010-164

Cooper, M.R., Anderson, P., Condon, D.J., Stevenson, C.T.E., Ellam, R.M., Meighan, I.G. \& Crowley, Q.G. 2016. Shape and intrusion history of the Late Caledonian, Newry Igneous Complex, Northern Ireland. In: Young, M.E. (ed.) Unearthed: Impacts of the Tellus Surveys of Ireland. Royal Irish Academy, Dublin, 145-155, https://doi.org/10.3318/ 978-1-908996-88-6.ch11

Daly, J.S. 1996. Pre-Caledonian history of the Annagh Gneiss Complex, Northwestern Ireland, and correlation with Laurentia-Baltica. Irish Journal of Earth Sciences, 15, 5-18.

Dewey, J.F. \& Strachan, R.A. 2003. Changing Silurian-Devonian relative plate motion in the Caledonides: sinistral transpression to sinistral transtension. Journal of the Geological Society, London, 160, 219-229, https://doi.org/10. 1144/0016-764902-085

Dodson, M.H., Compston, W., Williams, I.S. \& Wilson, J.F. 1988. A search for ancient detrital zircons in Zimbabwean sediments. Journal of the Geological Society, London, 145, 977-983, https://doi.org/10.1144/gsjgs.145.6.0977

Dorais, M.J., Wintsch, R.P., Kunk, M.J., Aleinikoff, J., Burton, W., Underdown, C. \& Kerwin, C.M. 2012. $P-T-t$ conditions, $\mathrm{Nd}$ and $\mathrm{Pb}$ isotopic compositions and detrital zircon geochronology of the Massabesic Gneiss Complex, New Hampshire: Isotopic and metamorphic evidence for the identification of Gander basement, central New England. American Journal of Science, 312, 1049-1097, https://doi.org/10.2475/10.2012.01

Ennis, M., Meere, P.A., Timmerman, M.J. \& Sudo, M. 2015. Post-Acadian sediment recycling in the Devonian Old Red Sandstone of Southern Ireland. Gondwana Research, 28, 1415-1433, https://doi.org/10.1016/j.gr.2014.10. 007

Fernandez-Suarez, J., Gutierrez Alonso, G. \& Jeffries, T.E. 2002. The importance of along-margin terrane transport in northern Gondwana: Insights from detrital zircon parentage in Neoproterozoic rocks from Iberia and Brittany. Earth and Planetary Science Letters, 204, 75-88, https://doi.org/10.1016/S0012-821X (02)00963-9

Force, E.R. \& Barr, S.M. 2012. Provenance of the Lower Carboniferous Horton Group, Petit-de-Grat Island, Nova Scotia, as revealed by detrital zircon ages. Atlantic Geology, 48, 137-145, https://doi.org/10.4138/atlgeol.2012.007

Ford, M., Brown, C. \& Readman, P. 1991. Analysis and tectonic interpretation of gravity data over the Variscides of southwest Ireland. Journal of the Geological Society, London, 148, 137-148, https://doi.org/10.1144/gsjgs. 148.1.0137

Ford, M., Klemperer, S.L. \& Ryan, P.D. 1992. Deep structure of southern Ireland: a new geological synthesis using BIRPS deep reflection profiling. Journal of the Geological Society, London, 149, 915-922.
Friend, C.R.L., Strachan, R.A., Kinny, P.D. \& Watt, G.R. 2003. Provenance of the Moine Supergroup of NW Scotland: evidence from geochronology of detrital and inherited zircons from (meta) sedimentary rocks, granites and migmatites. Journal of the Geological Society, London, 160, 247-257, https:// doi.org/10.1144/0016-764901-161

Fritschle, T., Daly, J.S., Whitehouse, M.J., McConnell, B. \& Buhre, S. 2017. Multiple intrusive phases in the Leinster Batholith, Ireland: geochronology, isotope geochemistry and constraints on the deformation history, Journal of the Geological Society, first published online October 12, 2017, https://doi. org/10.1144/jgs2017-034

Fullea, J., Muller, M.R., Jones, A.G. \& Afonso, J.C. 2014. The lithosphereasthenosphere system beneath Ireland from integrated geophysical-petrological modeling II: 3D thermal and compositional structure. Lithos, 189, 49-64, https://doi.org/10.1016/j.lithos.2013.09.014

Fyffe, L.R., Barr, S.M. et al. 2009. Detrital zircon ages from Neoproterozoic and Early Paleozoic conglomerate and sandstone units of New Brunswick and coastal Maine: implications for the tectonic evolution of Ganderia. Atlantic Geology, 45, 110-144, https://doi.org/10.4138/atlgeol.2009.006

Gallagher, K., Brown, R. \& Johnson, C. 1998. Fission track analysis and its applications to geological problems. Annual Review of Earth and Planetary Sciences, 26, 519-572, https://doi.org/10.1146/annurev.earth.26.1.519

Gehrels, G.E., Valencia, V.A. \& Ruiz, J. 2008. Enhanced precision, accuracy, efficiency, and spatial resolution of $\mathrm{U}-\mathrm{Pb}$ ages by laser ablation-multicollector-inductively coupled plasma-mass spectrometry. Geochemistry, Geophysics, Geosystems, 9, 1-13, https://doi.org/10.1029/2007GC001805

Henderson, B.J., Collins, W.J., Murphy, J.B., Gutierrez-Alonso, G. \& Hand, M. 2016. Gondwanan basement terranes of the Variscan-Appalachian orogen Baltican, Saharan and West African hafnium isotopic fingerprints in Avalonia Iberia and the Armorican Terranes. Tectonophysics, 681, 278-304, https://doi. org/10.1016/j.tecto.2015.11.020

Hibbard, J.P., Van Staal, C.R. \& Rankin, D.W. 2007. A comparative analysis of pre-Silurian crustal building blocks of the northern and the southern Appalachian orogen. American Journal of Science, 307, 23-45, https://doi. org/10.2475/01.2007.02

Higgs, K.T. 1999. Early Devonian spore assemblages from the Dingle Group, County Kerry, Ireland. Bollettino della Società Paleontologica Italiana, $\mathbf{3 8}$, 187-196.

Ijlst, L. 1973. A laboratory overflow-centrifuge for heavy liquid mineral separation. American Mineralogist, 58, 1088-1093.

Johnson, T.E., Kirkland, C.L., Reddy, S.M., Evans, N.J. \& McDonald, B.J. 2016 The source of Dalradian detritus in the Buchan Block, NE Scotland: application of new tools to detrital datasets. Journal of the Geological Society London, 173, 773-782, https://doi.org/10.1144/jgs2016-019

Kennedy, M.J. 1979. The continuation of the Canadian Appalachians into the Caledonides of Britain and Ireland. In: Harris, A.L., Holland, C.H. \& Leake, B.E. (eds) The Caledonides of the British Isles - Reviewed. Geological Society, London, Special Publications, 8, 33-64, https://doi.org/10.1144/ GSL.SP.1979.008.01.03

Keppie, J.D., Davis, D.W. \& Krogh, T.E. 1998. U-Pb geochronological constraints on Precambrian stratified units in the Avalon Composite Terrane of Nova Scotia, Canada: tectonic implications. Canadian Journal of Earth Sciences, 35, 222-236, https://doi.org/10.1139/e97-109

Keppie, J.D., Nance, R.D., Murphy, J.B. \& Dostal, J. 2003. Tethyan, Mediterranean, and Pacific analogues for the Neoproterozoic-Paleozoic birth and development of peri-Gondwanan terranes and their transfer to Laurentia and Laurussia. Tectonophysics, 365, 195-219, https:/doi.org/10.1016/S0040-1951(03)00037-4

Kirkland, C.L., Strachan, R.A. \& Prave, A.R. 2008. Detrital zircon signature of the Moine Supergroup, Scotland: Contrasts and comparisons with other Neoproterozoic successions within the circum-North Atlantic region Precambrian Research, 163, 332-350, https://doi.org/10.1016/j.precamres. 2008.01.003

Kostov, I. 1973. Zircon morphology as a crystallogenetic indicator. Kristall und Technik, 8, 11-19, https://doi.org/10.1002/crat.19730080103

Krogh, T.E. \& Keppie, J.D. 1990. Age of detrital zircon and titanite in the Meguma Group, southern Nova Scotia, Canada: Clues to the origin of the Meguma Terrane. Tectonophysics, 177, 307-323, https://doi.org/10.1016/ 0040-1951(90)90287-I

Kuiper, K.F., Deino, A., Hilgen, F.J., Krijgsman, W., Renne, P.R. \& Wijbrans, J. R. 2008. Synchronizing rock clocks of Earth history. Science, 320, 500-504, https://doi.org/10.1126/science.1154339

Linnemann, U., Gerdes, A., Drost, K. \& Buschmann, B. 2007. The continuum between Cadomian orogenesis and opening of the Rheic Ocean: Constraints from LA-ICP-MS U-Pb zircon dating and analysis of plate-tectonic setting (Saxo-Thuringian zone, northeastern Bohemian Massif, Germany). In: Linnemann, U., Nance, R.D., Kraft, P. \& Zulauf, G. (eds) The Evolution of the Rheic Ocean: From Avalonian-Cadomian Active Margin to AlleghenianVariscan Collision. Geological Society of America, Special Papers, 423 61-96, https://doi.org/10.1130/2007.2423(03)

Linnemann, U., Pereira, F., Jeffries, T.E., Drost, K. \& Gerdes, A. 2008. The Cadomian Orogeny and the opening of the Rheic Ocean: The diachrony of geotectonic processes constrained by LA-ICP-MS U-Pb zircon dating (OssaMorena and Saxo-Thuringian Zones, Iberian and Bohemian Massifs). Tectonophysics, 461, 21-43, https://doi.org/10.1016/j.tecto.2008.05.002

Linnemann, U., Herbosch, A., Liégeois, J.P., Pin, C., Gärtner, A. \& Hofmann, M. 2012. The Cambrian to Devonian odyssey of the Brabant Massif within 
Avalonia: A review with new zircon ages, geochemistry, Sm-Nd isotopes, stratigraphy and palaeogeography. Earth-Science Reviews, 112, 126-154, https://doi.org/10.1016/j.earscirev.2012.02.007

Livermore, R.A., Smith, A.G. \& Briden, J.C. 1985. Palaeomagnetic constraints on the distribution of continents in the Late Silurian and Early Devonian Philosophical Transactions of the Royal Society of London, Series B, 309, 29-56.

Ludwig, K.R. 2012. User's Manual for Isoplot 3.75. Berkeley Geochronology Centre Special Publication, 5.

Mac Niocaill, C. 2000. A new Silurian palaeolatitude for eastern Avalonia and evidence for crustal rotations in the Avalonian margin of southwestern Ireland. Geophysical Journal International, 141, 661-671, https://doi.org/10.1046/j. 1365-246X.2000.00101.X

Mark, C., Cogné, N. \& Chew, D. 2016. Tracking exhumation and drainage divide migration of the Western Alps: A test of the apatite $\mathrm{U}-\mathrm{Pb}$ thermochronometer as a detrital provenance tool. Geological Society of America Bulletin, 128, 1439-1460, https://doi.org/10.1130/B31351.1

Masson, F., Jacob, A.W.B., Prodehl, C., Readman, P.W., Shannon, P.M., Schulze, A. \& Enderle, U. 1998. A wide-angle seismic traverse through the Variscan of southwest Ireland. Geophysical Journal International, 134, 689-705, https://doi.org/10.1046/j.1365-246X.1998.00572.x

Max, M.D., Ploquin, A. \& Sonet, J. 1979. The age of the Saltees granite in the Rosslare Complex. In: Harris, A.L., Holland, C.H. \& Leake, B.E. (eds) The Caledonides of the British Isles - Reviewed. Geological Society, London, Special Publications, 8, 723-725, https://doi.org/10.1144/GSL.SP.1979.008. 01.88

Max, M.D., Barber, A.J. \& Martinez, J. 1990. Terrane assemblage of the Leinster Massif, SE Ireland, during the Lower Palaeozoic. Journal of the Geological Society, London, 147, 1035-1050, https://doi.org/10.1144/gsjgs.147.6.1035

McAteer, C.A., Daly, J.S., Flowerdew, M.J., Connelly, J.N., Housh, T.B. \& Whitehouse, M.J. 2010. Detrital zircon, detrital titanite and igneous clast $\mathrm{U}-\mathrm{Pb}$ geochronology and basement-cover relationships of the Colonsay Group, SW Scotland: Laurentian provenance and correlation with the Neoproterozoic Dalradian Supergroup. Precambrian Research, 181, 21-42, https://doi.org/10.1016/j.precamres.2010.05.013

McConnell, B. \& Morris, J. 1997. Initiation of Iapetus subduction under Irish Avalonia. Geological Magazine, 134, 213-218.

McConnell, B., Riggs, N. \& Crowley, Q.G. 2009. Detrital zircon provenance and Ordovician terrane amalgamation, western Ireland. Journal of the Geological Society, London, 166, 473-484, https://doi.org/10.1144/0016-76492008-081

McConnell, B., Crowley, Q.G. \& Riggs, N. 2010. Laurentian origin of the Ordovician Grangegeeth volcanic arc terrane, Ireland. Journal of the Geological Society, London, 167, 469-474, https://doi.org/10.1144/001676492009-139

McConnell, B., Parkes, M., Crowley, Q. \& Rushton, A. 2015. No Exploits backarc basin in the Iapetus suture zone of Ireland. Journal of the Geological Society, London, 172, 740-747, https://doi.org/10.1144/jgs2015-044

McConnell, B., Rogers, R. \& Crowley, Q. 2016. Sediment provenance and tectonics on the Laurentian margin: implications of detrital zircons ages from the Central Belt of the Southern Uplands-Down-Longford Terrane in Co. Monaghan, Ireland. Scottish Journal of Geology, 52, 11-17, https://doi.org/ 10.1144/sjg2015-013

McDowell, F.W., McIntosh, W.C. \& Farley, K.A. 2005. A precise ${ }^{40} \mathrm{Ar}-{ }^{39} \mathrm{Ar}$ reference age for the Durango apatite $(\mathrm{U}-\mathrm{Th}) / \mathrm{He}$ and fission-track dating standard. Chemical Geology, 214, 249-263, https://doi.org/10.1016/j. chemgeo.2004.10.002

McIlroy, D. \& Horák, J.M. 2006. Neoproterozoic: the late Precambrian terranes that formed Eastern Avalonia. In: Brenchley, P.J. \& Rawson, P.F. (eds) The Geology of England and Wales. Geological Society, London, 9-24, https:// doi.org/10.1144/GOEWP2

Meere, P. 1995. The structural evolution of the western Irish Variscides: an example of obstacle tectonics? Tectonophysics, 246, 97-112.

Meere, P.A. \& Mulchrone, K.F. 2006. Timing of deformation within Old Red Sandstone lithologies from the Dingle Peninsula, SW Ireland. Journal of the Geological Society, London, 163, 461-469, https://doi.org/10.1144/0016764905-099

Murphy, T. 1960. Gravity map in Ireland - sheet 5 - south west. Geophysical Bulletin, 18

Murphy, J.B., Fernández-Suárez, J. \& Jeffries, T.E. 2004a. Lithogeochemical and $\mathrm{Sm}-\mathrm{Nd}$ and $\mathrm{U}-\mathrm{Pb}$ isotope data from the Silurian-Lower Devonian Arisaig Group clastic rocks, Avalon terrane, Nova Scotia: A record of terrane accretion in the Appalachian-Caledonide orogen. Geological Society of America Bulletin, 116, 1183, https://doi.org/10.1130/B25423.1

Murphy, J.B., Fernández-Suárez, J., Jeffries, T.E. \& Strachan, R.A. 2004b. U-Pb (LA-ICP-MS) dating of detrital zircons from Cambrian clastic rocks in Avalonia: erosion of a Neoproterozoic arc along the northern Gondwanan margin. Journal of the Geological Society, London, 161, 243-254, https://doi. org/10.1144/0016-764903-064

Nance, R.D., Murphy, J.B. et al.. 2008. Neoproterozoic-early Palaeozoic tectonostratigraphy and palaeogeography of the peri-Gondwanan terranes: Amazonian v. West African connections. In: Ennih, N. \& Liégeois, J.-P. (eds) The Boundaries of the West African Craton. Geological Society of London, Special Publications, 297, 345-383, https://doi.org/10.1144/SP297.17

Nance, R.D., Gutiérrez-Alonso, G. et al.. 2012. A brief history of the Rheic Ocean Geoscience Frontiers, 3, 125-135, https://doi.org/10.1016/j.gsf.2011.11.008
Nance, R., Neace, E., Braid, J., Murphy, J., Dupuis, N. \& Shail, R. 2015. Does the Meguma Terrane extend into SW England? Geoscience Canada, 42, 61-76, https://doi.org/10.12789/geocanj.2014.41.056

O’Connor, P.J., Kennan, P.S. \& Aftalion, M. 1988. New Rb-Sr and U-Pb ages for the Carnsore Granite and their bearing on the antiquity of the Rosslare Complex, southeastern Ireland. Geological Magazine, 125, 25-29, https://doi. org/10.1017/S0016756800009341

O’Connor, P.J., Aftalion, M. \& Kennan, P.S. 1989. Isotopic U-Pb ages of zircon and monazite from the Leinster Granite, southeast Ireland. Geological Magazine, 126, 725-728, https://doi.org/10.1017/S0016756800007044

Owen, A.W. \& Parkes, M.A. 2000. Trilobite faunas of the Duncannon Group: Caradoc stratigraphy, environments and palaeobiogeography of the Leinster terrane, Ireland. Palaeontology, 43, 219-269, https://doi.org/10.1111/14754983.00125

Paton, C., Hellstrom, J., Paul, B., Woodhead, J. \& Hergt, J. 2011. Iolite: Freeware for the visualisation and processing of mass spectrometric data. Journal of Analytical Atomic Spectrometry, 26, 2508-2518, https://doi.org/10.1039/ clja10172b

Penney, S. 1980. A new look at the Old Red Sandstone succession of the Comeragh Mountains, County Waterford. Journal of Earth Sciences, 3, 155-178.

Phillips, E.R., Barnes, R.P., Boland, M.P., Fortey, N.J. \& McMillan, A.A. 1995. The Moniaive Shear Zone: a major zone of sinistral strike-slip deformation in the Southern Uplands of Scotland. Scottish Journal of Geology, 31, 139-149, https://doi.org/10.1144/sjg31020139

Pickering, K.T., Bassett, M.G. \& Siveter, D.J. 1988. Late Ordovician-early Silurian destruction of the Iapetus Ocean: Newfoundland, British Isles and Scandinavia - a discussion. Transactions of the Royal Society of Edinburgh: Earth Sciences, 79, 361-382.

Pointon, M.A., Cliff, R.A. \& Chew, D.M. 2012. The provenance of Western Irish Namurian Basin sedimentary strata inferred using detrital zircon U-Pb LAICP-MS geochronology. Geological Journal, 47, 77-98, https://doi.org/10. 1002/gj.1335

Poldervaart, A. 1955. Zircons in rocks; Part 1, Sedimentary rocks; Part 2, Igneous rocks. American Journal of Science, 253, 433-461, https://doi.org/10.2475/ ajs.253.8.433

Pollock, J.C. 2007. The Neoproterozoic-Early Paleozoic Tectonic Evolution of the Peri-Gondwanan Margin of the Appalachian Orogen - an Integrated Geochronological, Geochemical and Isotopic Study from North Carolina and Newfoundland. PhD thesis, North Carolina State University.

Pollock, J.C., Hibbard, J.P. \& Van Staal, C.R. 2012. A paleogeographical review of the peri-Gondwanan realm of the Appalachian orogen. Canadian Journal of Earth Sciences, 49, 259-288, https://doi.org/10.1139/E11-049

Pothier, H.D., Waldron, J.W.F., Schofield, D.I. \& DuFrane, S.A. 2015. PeriGondwanan terrane interactions recorded in the Cambrian-Ordovician detrital zircon geochronology of North Wales. Gondwana Research, 28, 987-1001, https://doi.org/10.1016/j.gr.2014.08.009

Samson, S.D., D'Lemos, R.S., Miller, B.V. \& Hamilton, M.A. 2005. Neoproterozoic palaeogeography of the Cadomia and Avalon terranes: constraints from detrital zircon U-Pb ages. Journal of the Geological Society, London, 162, 65-71, https://doi.org/10.1144/0016-764904-003

Satkoski, A.M., Barr, S.M. \& Samson, S.D. 2010. Provenance of Late Neoproterozoic and Cambrian sediments in Avalonia: constraints from detrita zircon ages and $\mathrm{Sm}-\mathrm{Nd}$ isotopic compositions in southern New Brunswick, Canada. Journal of Geology, 118, 187-200, https://doi.org/10.1086/649818

Schoene, B. \& Bowring, S.A. 2006. U-Pb systematics of the McClure Mountain syenite: thermochronological constraints on the age of the ${ }^{40} \mathrm{Ar} /{ }^{39} \mathrm{Ar}$ standard MMhb. Contributions to Mineralogy and Petrology, 151, 615-630, https:// doi.org/10.1007/s00410-006-0077-4

Schofield, D., Potter, J., Barr, S.M., Horak, J., Millar, I.L. \& Longstaffe, F. 2016 Reappraising the Neoproterozoic 'East Avalonian' terranes of southern Great Britain. Gondwana Research, 35, 257-271, https://doi.org/10.1016/j.gr.2015. 06.001

Soper, N.J. \& Hutton, D.H.W. 1984. Late Caledonian sinistral displacements in Britain: Implication for a three-plate model. Tectonics, 3, 781-794.

Soper, N.J. \& Woodcock, N.H. 2003. The lost Lower Old Red Sandstone of England and Wales: a record of post-Iapetan flexure or Early Devonian transtension? Geological Magazine, 140, 627-647, https://doi.org/10.1017/ S0016756803008380

Stacey, J.S. \& Kramers, J.D. 1975. Approximation of terrestrial lead isotope evolution by a two-stage model. Earth and Planetary Science Letters, 26, 207-221, https://doi.org/10.1016/0012-821X(75)90088-6

Strachan, R.A., Collins, A.S., Buchan, C., Nance, R.D., Murphy, J.B. \& D’Lemos, R.S. 2007. Terrane analysis along a Neoproterozoic active margin of Gondwana: insights from $\mathrm{U}-\mathrm{Pb}$ zircon geochronology. Journal of the Geological Society, London, 164, 57-60, https://doi.org/10.1144/0016-76492006-014

Strachan, R.A., Prave, A.R., Kirkland, C.L. \& Storey, C.D. 2013. U-Pb detrital zircon geochronology of the Dalradian Supergroup, Shetland Islands, Scotland: implications for regional correlations and NeoproterozoicPalaeozoic basin development. Journal of the Geological Society, London, 170, 905-916, https://doi.org/10.1144/jgs2013-057

Strachan, R.A., Linnemann, U., Jeffries, T., Drost, K. \& Ulrich, J. 2014 Armorican provenance for the melange deposits below the Lizard ophiolite (Cornwall, UK): Evidence for Devonian obduction of Cadomian and Lower Palaeozoic crust onto the southern margin of Avalonia. International Journal of Earth Sciences, 103, 1359-1383, https://doi.org/10.1007/s00531-013-0961-X 
Thompson, M.D. \& Bowring, S.A. 2000. Age of the Squantum 'Tillite,' Boston Basin, Massachusetts: U-Pb zircon constraints on terminal Neoproterozoic glaciation. American Journal of Science, 300, 630-655, https://doi.org/10. 2475/ajs.300.8.630

Thompson, M.D., Barr, S.M. \& Grunow, A.M. 2012. Avalonian perspectives on Neoproterozoic paleogeography: Evidence from Sm-Nd isotope geochemistry and detrital zircon geochronology in SE New England, USA. Geological Society of America Bulletin, 124, 517-531, https://doi.org/10.1130/B30529.1

Thomson, S.N., Gehrels, G.E., Ruiz, J. \& Buchwaldt, R. 2012. Routine low-damage apatite $\mathrm{U}-\mathrm{Pb}$ dating using laser ablation-multicollector-ICPMS. Geochemistry, Geophysics, Geosystems, 13, https://doi.org/10.1029/2011GC003928

Todd, S.P. 1989. Role of the Dingle Bay Lineament in the evolution of the Old Red Sandstone of southwest Ireland. In: Arthurton, R., Gutteridge, P. \& Nolan, S. (eds) The Role of Tectonics in Devonian and Carboniferous Sedimentation in the British Isles. Yorkshire Geological Society, Bradford, 35-54.

Todd, S.P. 2000. Taking the roof off a suture zone: basin setting and provenance of conglomerates in the ORS Dingle Basin of SW Ireland. In: Friend, P.F. \& Williams, B.P.J. (eds) New Perspectives on the Old Red Sandstone. Geological Society, London, Special Publications, 180, 185-222, https://doi.org/10.1144/ GSL.SP.2000.180.01.10

Todd, S.P. 2015. Structure of the Dingle Peninsula, SW Ireland: evidence for the nature and timing of Caledonian, Acadian and Variscan tectonics. Geological Magazine, 152, 242-268, https://doi.org/10.1017/S0016756814000260

Todd, S.P., Williams, B.P.J. \& Hancock, P.L. 1988. Lithostratigraphy and structure of the Old Red Sandstone of the Northern Dingle Peninsula, Co. Kerry, southwest Ireland. Geological Journal, 23, 107-120.

Todd, S.P., Murphy, F.C. \& Kennan, P.S. 1991. On the trace of the Iapetus suture in Ireland and Britain. Journal of the Geological Society, London, 148, 869-880, https://doi.org/10.1144/gsjgs.148.5.0869

Todd, S.P., Connery, C., Higgs, K.T. \& Murphy, F.C. 2000. An Early Ordovician age for the Annascaul Formation of the SE Dingle Peninsula, SW Ireland. Journal of the Geological Society, London, 157, 823-833, https://doi.org/10. $1144 /$ jgs.157.4.823

Tyrrell, S., Haughton, P.D.W. \& Daly, J.S. 2007. Drainage reorganization during breakup of Pangea revealed by in-situ $\mathrm{Pb}$ isotopic analysis of detrital K-feldspar. Geology, 35, 971-974, https://doi.org/10.1130/G4123A.1

Van der Voo, R. 1983. Paleomagnetic constraints on the assembly of the Old Red Continent. Tectonophysics, 91, 271-283.

Van der Voo, R. 1988. Paleozoic paleogeography of North America, Gondwana, and intervening displaced terranes: Comparisons of paleomagnetism with paleoclimatology and biogeographical patterns. Geological Society of America Bulletin, 100, 311-324.

Van Staal, C.R., Sullivan, R.W. \& Whalen, J.B. 1996. Provenance and tectonic history of the Gander Zone in the Caledonian/Appalachian orogen: Implications for the origin and assembly of Avalon. In: Nance, R.D. \& Thompson, M.D. (eds) Avalonian and Related peri-Gondwanan Terranes of the Circum-North Atlantic. Geological Society of American, Special Papers, 304, 347-367.

Van Staal, C.R., Dewey, J.F., Niocaill, C.M. \& McKerrow, W.S. 1998. The Cambrian-Silurian tectonic evolution of the northern Appalachians and British Caledonides: history of a complex, west and southwest Pacific-type segment of Iapetus. In: Blundell, D.J. \& Scott, A.C. (eds) Lyell: The Past is the Key to the Present. Geological Society, London, Special Publications, 143, 197-242, https://doi.org/10.1144/GSL.SP.1998.143.01.17

Vermeesch, P. 2012. On the visualisation of detrital age distributions. Chemical Geology, 312-313, 190-194, https://doi.org/10.1016/j.chemgeo.2012.04.021

Vermeesch, P. 2013. Multi-sample comparison detrital age distributions. Chemical Geology, 341, 140-146, https://doi.org/10.1016/j.chemgeo.2013.01.010

Vermeesch, P., Resentini, A. \& Garzanti, E. 2016. An R package for statistical provenance analysis. Sedimentary Geology, 336, 14-25, https://doi.org/10. 1016/j.sedgeo.2016.01.009
Vermeulen, N.J., Shannon, P.M., Masson, F. \& Landes, M. 2000. Wide-angle seismic control on the development of the Munster Basin, SW Ireland. In: Friend, P.F. \& Williams, B.P.J. (eds) New Perspectives on the Old Red Sandstone. Geological Society, London, Special Publications, 180, 223-237, https://doi.org/10.1144/GSL.SP.2000.180.01.11

Waldron, J.W.F., Floyd, J.D., Simonetti, A. \& Heaman, L.M. 2008. Ancien Laurentian detrital zircon in the closing Iapetus ocean, Southern Uplands terrane, Scotland. Geology, 36, 527-530, https://doi.org/10.1130/ G24763A.1

Waldron, J.W.F., White, C.E., Barr, S.M., Simonetti, A. \& Heaman, L.M. 2009. Provenance of the Meguma terrane, Nova Scotia: rifted margin of early Paleozoic Gondwana. Canadian Journal of Earth Sciences, 46, 1-8, https:// doi.org/10.1139/E09-004

Waldron, J.W.F., Schofield, D.I., White, C.E. \& Barr, S.M. 2011. Cambrian successions of the Meguma Terrane, Nova Scotia, and Harlech Dome, North Wales: dispersed fragments of a peri-Gondwanan basin? Journal of the Geological Society, London, 168, 83-98, https://doi.org/10.1144/001676492010-068.Cambrian

Waldron, J.W.F., Schofield, D.I. et al. 2014. Ganderia-Laurentia collision in the Caledonides of Great Britain and Ireland. Journal of the Geological Society, London, 171, 555-569, https://doi.org/10.1144/jgs2013-131

Wetherill, G. 1956. Discordant uraniam-lead ages, I. Transactions, American Geophysical Union, 37, 320-326.

White, C.E., Palacios, T., Jensen, S. \& Barr, S.M. 2012. Cambrian-Ordovician acritarchs in the Meguma terrane, Nova Scotia, Canada: Resolution of early Paleozoic stratigraphy and implications for paleogeography. Geological Society of America Bulletin, 124, 1773-1792, https://doi.org/10.1130/ B30638.1

Williams, E.A. 2000. Flexural cantilever models of extensional subsidence in the Munster Basin (SW Ireland) and Old Red Sandstone fluvial dispersal systems. In: Friend, P.F. \& Williams, B.P.J. (eds) New Perspectives on the Old Red Sandstone. Geological Society, London, Special Publications, 180, 239-268, https://doi.org/10.1144/GSL.SP.2000.180.01.12

Williams, E.A., Sergeev, S.A., Stossel, I., Ford, M. \& Higgs, K.T. 1999. U-Pb zircon geochronology of silicic tuffs from the Old Red Sandstone of the Dingle and Munster Basins (SW Ireland): refining the Devonian time scale. EUG Journal of Conference Abstracts, 4, 805.

Williams, E.A., Sergeev, S.A., Stossel, I., Ford, M. \& Higgs, K.T. 2000. U-Pb zircon geochronology of silicic tuffs and chronostratigraphy of the earliest Old Red Sandstone in the Munster Basin, SW Ireland. In: Friend, P.F. \& Williams, B.P.J. (eds) New Perspectives on the Old Red Sandstone. Geological Society, London, Special Publications, 180, 269-302, https://doi.org/10.1144/GSL.SP 2000.180.01.13

Willner, A.P., Barr, S.M., Gerdes, A., Massonne, H.J \& White, C.E 2013. Origin and evolution of Avalonia: evidence from $\mathrm{U}-\mathrm{Pb}$ and $\mathrm{Lu}-\mathrm{Hf}$ isotopes in zircon from the Mira terrane, Canada, and the Stavelot-Venn Massif, Belgium. Journal of the Geological Society, London, 170, 769-784, https://doi.org/10. 1144/jgs2012-152

Willner, A.P., Gerdes, A., Massonne, H.-J., Van Staal, C.R. \& Zagorevski, A 2014. Crustal evolution of the northeast Laurentian margin and the PeriGondwanan microcontinent Ganderia prior to and during closure of the Iapetus Ocean: detrital zircon $\mathrm{U}-\mathrm{Pb}$ and $\mathrm{Hf}$ isotope evidence from Newfoundland. Geoscience Canada, 41, 345-364.

Woodcock, N.H. 2012. Ordovician volcanism and sedimentation on eastern Avalonia. In: Woodcock, N.H. \& Strachan, R.A. (eds) Geological History of Britain and Ireland. Blackwell, Oxford, 162-176.

Zattin, M., Andreucci, B., Thomson, S.N., Reiners, P.W. \& Talarico, F.M. 2012. New constraints on the provenance of the ANDRILL AND-2A succession (western Ross Sea, Antarctica) from apatite triple dating. Geochemistry, Geophysics, Geosystems, 13, https://doi.org/10.1029/2012GC004357 